\title{
Geochemistry, Paragenesis, and Wall-Rock Alteration of the Qatruyeh Iron Deposits, Southwest of Iran: Implications for a Hydrothermal-Metasomatic Genetic Model
}

\author{
Sina Asadi and Mohammad Ali Rajabzadeh \\ Department of Earth Sciences, Faculty of Sciences, Shiraz University, Shiraz 7146713565, Iran \\ Correspondence should be addressed to Sina Asadi; sinaasadi@shirazu.ac.ir
}

Received 16 June 2014; Accepted 27 August 2014; Published 22 October 2014

Academic Editor: Salvatore Gambino

Copyright ( 2014 S. Asadi and M. A. Rajabzadeh. This is an open access article distributed under the Creative Commons Attribution License, which permits unrestricted use, distribution, and reproduction in any medium, provided the original work is properly cited.

\begin{abstract}
The Qatruyeh iron deposits, located on the eastern border of the NW-SE trending Sanandaj-Sirjan metamorphic zone, southwest of Iran, are hosted by a late Proterozoic to early Paleozoic sequence dominated by metamorphosed carbonate rocks. The magnetite ores occurred as layered to massive bodies, with lesser amounts of disseminated magnetite and hematite-bearing veins. Textural evidences, along with geochemical analyses of the high field strengths (HFSEs), large ion lithophiles (LILEs), and rare earth elements (REEs), indicate that the main mineralization stage occurred as low-grade layered magnetite ores due to high-temperature hydrothermal fluids accompanied by $\mathrm{Na}-\mathrm{Ca}$ alteration. Most of the main ore-stage minerals precipitated from an aqueous-carbonic fluid (3.5-15 wt. $\% \mathrm{NaCl}$ equiv.) at temperatures ranging between $300^{\circ}$ and $410^{\circ} \mathrm{C}$ during fluid mixing process, $\mathrm{CO}_{2}$ effervescence, cooling, and increasing of $\mathrm{pH}$. Low-temperature hydrothermal activity subsequently produced hematite ores associated with propylitic alteration. The metacarbonate host rocks are LILE-depleted and HFSE-enriched due to metasomatic alteration.
\end{abstract}

\section{Introduction}

The last decade has seen major progress in our understanding of the origin of iron ore deposits worldwide. The majority of interpretations focused on the igneous iron oxide deposits either having formed by magmatic liquid immiscibility [1-7] or by hydrothermal alteration and replacement [8-14]. The hydrothermal iron deposits generally are found at many locations around the Pacific basin, Central America, Australia, and Japan [15]. They are commercially far less important as global source of iron than banded iron formations and igneous iron deposits, except for many countries without these types of iron deposits. Genetic models for hydrothermal Fe-oxide deposits associated with hybrid magmatic to nonmagmatic fluids, which locally mix at the trap site [16], suggest that metamorphic processes or a primary felsic to intermediate intrusion could be regarded as source of the majority of hydrothermal fluids and metals $[17,18]$. Therefore, metasomatic iron-rich fluid regimes are associated with magmatism or metamorphism, or both. Depending on the physicochemical conditions the protore iron mineralization could consist of magnetite or hematite, or a mix of the two. They occur in different tectonic environments, such as intracontinental terranes associated with anorogenic magmatism, continental arc terranes, and metamorphic belts [18-20].

The most favorable area for hydrothermal ore deposits in Iran is the Sanandaj-Sirjan zone (SSZ), which has a NW-SE trend and is characterized by magmatism-metamorphism and an obliquely thrusted wedge, with asymmetrical structures in the HP-LT metamorphic rocks [21]. This metamorphic belt contains abundance of iron ore deposits, including the Gol-Gohar (Kerman), Totak, Dehbid (Fars), Galali, Baba-Ali (Hamedan), and Shams-Abad (Arak). However, distribution of these deposits from NW toward SE Sanandaj-Sirjan is very important but the origin of these deposits has been a subject of heated debate. Eshraghi et al. [21] were the first to present the details of the geology and genesis of the Gol-Gohar and the Qatruyeh deposits and proposed metamorphism as main factor controlling the mineralization. However, based on textural and geochemical 
evidence, [22-24] suggested iron oxide-copper-gold (IOCG) origin for Sanandaj-Sirjan iron deposits. According to [25], the iron deposits from Hamadan to Gol-Gohar situated in the Sanandaj-Sirjan zone about $1200 \mathrm{~km}$ apart and show striking mineralogical and textural similarities. They believed that the ore bodies are of magmatic origin and formed at late stages of hydrothermal conditions.

In spite of the existence of the important iron ore deposits in the Qatruyeh area, there are a few reports on the ores with no exploitation activities. This paper presents detailed field observations, mineralogical alteration assemblages, textural relationships, fluid inclusions and geochemical data on the ore bodies, and the associated dolomitic-marble host and plutonic rocks at the Qatruyeh iron ores, southwest of Iran, in order to reveal a genetic model for the deposits in the area.

\section{Methods}

Major and trace elements analyses were carried out on representative samples using inductively coupled plasma optical emission spectroscopy (ICP-OES), with $0.1 \mathrm{ppm}$ detection limit at Geological Survey of Iran (22 ore samples), and using standard wet chemical analysis by flame atomic absorption spectrophotometry (FAAS), with $0.5 \mathrm{ppm}$ detection limit at the Department of Earth Sciences, at Shiraz University (5 fresh marbles, 11 altered marbles, and 12 diorites). Rare earth elements (REE) were analyzed by inductively coupled plasma mass spectrometry (ICP-MS) with $0.01 \mathrm{ppm}$ detection limit at ALS Chemex Analytical Services, Canada (4 diorites and 22 ore samples). Sample locations are shown in Table 1 and they are described with regard to type of analyses.

\section{Geological Setting and Lithostratigraphy}

The Qatruyeh area is located about $50 \mathrm{~km}$ NE of Neyriz and lies within the Zagros orogenic belt in SW of Iran. The Zagros orogenic belt of Iran consists of three parallel tectonic domains: (1) the Urumieh-Dokhtar magmatic belt (UDMB), (2) the Sanandaj-Sirjan zone (SSZ), and (3) the Zagros foldedthrust belt (ZFTB) [35]. The iron deposits are located in the eastern margin of the NW-SE trending Sanandaj-Sirjan zone (Figure 1).

The SSZ consists of Paleozoic to Triassic high-grade metamorphic rocks overlaid by Mesozoic metasedimentary strata. The Mesozoic sediments were deposited along a passive continental margin [36-39] and subsequently largescale Mesozoic plutons ranging from gabbro to granite, emplaced in about $160 \pm 10 \mathrm{Ma}$ by the K-Ar methods [40]. The ore bodies show a strong deformation in parallel to the regional west-northwest structural trend. Lithostratigraphic relationships in the Qatruyeh area are summarized in Figure 2. Some researchers $[40,41]$ recognized five rock groups in Neyriz area, from base to top and from low- to highgrade metamorphic rocks, which are unconformably overlaid by Upper Triassic turbiditc rocks and basalt. These groups include the following.

Group A. Homogeneous orthogneiss with some amphibolite lenses and small bodies of anatectic granite. The orthogneiss has been dated by $\mathrm{U}-\mathrm{Pb}$ method on zircons, at $520 \mathrm{Ma}$ [41].

Group B. Alternation of amphibolite, migmatite, minor micaschist, marble, and metamorphosed mafic and ultramafic rocks. The age of the metamorphic rocks is $310 \mathrm{Ma}$ based on ${ }^{40} \mathrm{~K}-{ }^{40} \mathrm{Ar}$ dating method on extracted white mica, biotite, plagioclase, and amphibole.

Group C. Micaschist, calc-schist, marble, minor amphibolite, and mafic to ultramafic rocks. Along the SanandajSirjan zone, comparable rocks yielded deformed Devonian corals $[21,42,43]$. The Chah Pazhan metagabbro contains medium-grained clinopyroxene (e.g., augite, hedenbergite, and pigeonite), plagioclase feldspar, and orthopyroxenes (e.g., enstatite). The clinopyroxenes have been amphibolized and uralitized (actinolitization-tremolitization).

Group D. Schist, slate, calc-schist, metabasite, quartzite, and intercalations of marble. The metacarbonate intercalations are more frequent towards the upper part of the group. Palynomorphs (Galyptosporites, Laevigatosporites, Polyedrxium sp., Ancyspora sp., Geminospora sp., and Relusotrilletes sp.) indicate a late Devonian-early Carboniferous age for this group [21].

Group E. Limestone, dolomite, basalt, and synsedimentary monogenetic breccias. Above the early Cimmerian unconformity, the Upper Triassic and Jurassic sequence were deposited in turbiditic basins, geometry of which is still poorly known [40]. These rocks show a weak but obvious cleavage, indicative of a deformation that affects the upper Triassic and Jurassic conglomerates and sandstones, but not the overlying Cretaceous series in adjacent areas.

The Deh Vazir Jurassic deformed conglomerate is located in the north part of the area and is sandwiched between two thrust sheets which are part of the Main Zagros Thrust zone. Most of the pebbles in this conglomerate consist of micaschist and phyllite [44], but at some localities, the presence of massive magnetite pebbles indicates the ore formation is prior to main metamorphism (Laramide phase) (Figure 3(a)). The conglomerate was occurred extensively in the area which covers metamorphosed limestones, turbidite shales, and sandstones.

\section{Deformation and Metamorphism}

The SSZ underwent polyphase deformation events during the Mesozoic era. The latest event recorded in the rocks reflects collision of the Afro-Arabian continent and Iranian microcontinents and subsequent southward propagation of the fold-thrust belt $[39,45,46]$. Geological and textural information suggest that there are at least three main deformation phases $\mathrm{D}_{1}, \mathrm{D}_{2}$, and $\mathrm{D}_{3}[47]$.

The regional lithologies at the Qatruyeh record a clockwise metamorphic path followed by thrust deformation events. The peak pressure and temperature in the upper Triassic and Jurassic sequences were estimated at $9.5 \pm$ $1.2 \mathrm{kbar}$ and $705 \pm 40^{\circ} \mathrm{C}$, respectively. Using zircon sensitive 
TABLE 1: Location and description of samples used for fluid inclusion and chemical analyses.

\begin{tabular}{|c|c|c|c|c|}
\hline Sample & Field number & Easting & Northing & Type of analysis \\
\hline Chah Anjir plutonic rocks & CAP 1 & $54^{\circ} 34^{\prime} 22.6^{\prime \prime}$ & $29^{\circ} 14^{\prime} 00.7^{\prime \prime}$ & ICP-OES, FAAS \\
\hline Chah Anjir plutonic rocks & CAP 2 & $54^{\circ} 34^{\prime} 27.8^{\prime \prime}$ & $29^{\circ} 14^{\prime} 14.7^{\prime \prime}$ & ICP-OES, FAAS \\
\hline Chah Anjir plutonic rocks & CAP 3 & $54^{\circ} 33^{\prime} 24.2^{\prime \prime}$ & $29^{\circ} 13^{\prime} 00.5^{\prime \prime}$ & ICP-OES, FAAS \\
\hline Chah Anjir plutonic rocks & CAP 4 & $54^{\circ} 34^{\prime} 19.7^{\prime \prime}$ & $29^{\circ} 14^{\prime} 26.1^{\prime \prime}$ & ICP-OES, FAAS \\
\hline Chah Anjir plutonic rocks & CAP 5 & $54^{\circ} 34^{\prime} 22.6^{\prime \prime}$ & $29^{\circ} 14^{\prime} 00.3^{\prime \prime}$ & ICP-OES, FAAS \\
\hline Chah Anjir plutonic rocks & CAP 6 & $54^{\circ} 33^{\prime} 22.5^{\prime \prime}$ & $29^{\circ} 14^{\prime} 00.9^{\prime \prime}$ & ICP-OES, FAAS \\
\hline Chah Anjir plutonic rocks & CAP 7 & $54^{\circ} 34^{\prime} 34.4^{\prime \prime}$ & $29^{\circ} 14^{\prime} 12.0^{\prime \prime}$ & ICP-MS, ICP-OES, FAAS \\
\hline Chah Anjir plutonic rocks & CAP 8 & $54^{\circ} 34^{\prime} 34.6^{\prime \prime}$ & $29^{\circ} 14^{\prime} 12.0^{\prime \prime}$ & ICP-MS, ICP-OES, FAAS \\
\hline Chah Anjir plutonic rocks & CAP 9 & $54^{\circ} 34^{\prime} 34.6^{\prime \prime}$ & $29^{\circ} 14^{\prime} 12.0^{\prime \prime}$ & ICP-MS, ICP-OES, FAAS \\
\hline Chah Anjir plutonic rocks & CAP 10 & $54^{\circ} 34^{\prime} 34.6^{\prime \prime}$ & $29^{\circ} 14^{\prime} 12.0^{\prime \prime}$ & ICP-MS, ICP-OES, FAAS \\
\hline Chah Anjir plutonic rocks & CAP 11 & $54^{\circ} 33^{\prime} 43.7^{\prime \prime}$ & $29^{\circ} 14^{\prime} 05.5^{\prime \prime}$ & ICP-OES, FAAS \\
\hline Chah Anjir plutonic rocks & CAP 12 & $54^{\circ} 33^{\prime} 43.7^{\prime \prime}$ & $29^{\circ} 14^{\prime} 05.5^{\prime \prime}$ & ICP-OES, FAAS \\
\hline Hematite ore & H1 & $54^{\circ} 35^{\prime} 21.1^{\prime \prime}$ & $29^{\circ} 16^{\prime} 46.3^{\prime \prime}$ & ICP-MS, ICP-OES, FAAS \\
\hline Hematite ore & $\mathrm{H} 2$ & $54^{\circ} 35^{\prime} 03.8^{\prime \prime}$ & $29^{\circ} 15^{\prime} 03.4^{\prime \prime}$ & ICP-MS, ICP-OES, FAAS \\
\hline Hematite ore & $\mathrm{H} 3$ & $54^{\circ} 40^{\prime} 32.7^{\prime \prime}$ & $29^{\circ} 14^{\prime} 13.6^{\prime \prime}$ & ICP-MS, ICP-OES, FAAS \\
\hline Massive magnetite ore & MM1 & $54^{\circ} 36^{\prime} 20.0^{\prime \prime}$ & $29^{\circ} 15^{\prime} 30.0^{\prime \prime}$ & ICP-MS, ICP-OES, FAAS \\
\hline Massive magnetite ore & MM2 & $54^{\circ} 35^{\prime} 56.8^{\prime \prime}$ & $29^{\circ} 16^{\prime} 14.4^{\prime \prime}$ & ICP-OES, FAAS \\
\hline Massive magnetite ore & MM3 & $54^{\circ} 36^{\prime} 40.3^{\prime \prime}$ & $29^{\circ} 15^{\prime} 35.1^{\prime \prime}$ & ICP-OES, FAAS \\
\hline Massive magnetite ore & MM4 & $54^{\circ} 36^{\prime} 00.0^{\prime \prime}$ & $29^{\circ} 15^{\prime} 36.2^{\prime \prime}$ & ICP-OES, FAAS \\
\hline Massive magnetite ore & MM5 & $54^{\circ} 36^{\prime} 00.4^{\prime \prime}$ & $29^{\circ} 15^{\prime} 32.6^{\prime \prime}$ & ICP-OES, FAAS \\
\hline Massive magnetite ore & MM6 & $54^{\circ} 36^{\prime} 10.0^{\prime \prime}$ & $29^{\circ} 15^{\prime} 36.1^{\prime \prime}$ & ICP-MS, ICP-OES, FAAS \\
\hline Massive magnetite ore & MM7 & $54^{\circ} 36^{\prime} 12.1^{\prime \prime}$ & $29^{\circ} 15^{\prime} 36.2^{\prime \prime}$ & ICP-MS, ICP-OES, FAAS \\
\hline Massive magnetite ore & MM8 & $54^{\circ} 36^{\prime} 20.4^{\prime \prime}$ & $29^{\circ} 15^{\prime} 30.0^{\prime \prime}$ & ICP-MS, ICP-OES, FAAS \\
\hline Layered magnetite ore & LM1 & $54^{\circ} 41^{\prime} 59.9^{\prime \prime}$ & $29^{\circ} 15^{\prime} 28.9^{\prime \prime}$ & ICP-MS, ICP-OES, FAAS \\
\hline Layered magnetite ore & LM2 & $54^{\circ} 39^{\prime} 40.0^{\prime \prime}$ & $29^{\circ} 14^{\prime} 11.2^{\prime \prime}$ & ICP-MS, ICP-OES, FAAS, FI \\
\hline Layered magnetite ore & LM3 & $54^{\circ} 39^{\prime} 26.3^{\prime \prime}$ & $29^{\circ} 14^{\prime} 14.7^{\prime \prime}$ & ICP-MS, ICP-OES, FAAS \\
\hline Layered magnetite ore & LM4 & $54^{\circ} 39^{\prime} 29.1^{\prime \prime}$ & $29^{\circ} 14^{\prime} 21.1^{\prime \prime}$ & ICP-OES, FAAS, FI \\
\hline Layered magnetite ore & LM5 & $54^{\circ} 39^{\prime} 40.0^{\prime \prime}$ & $29^{\circ} 14^{\prime} 21.7^{\prime \prime}$ & ICP-OES, FAAS, FI \\
\hline Layered magnetite ore & LM6 & $54^{\circ} 39^{\prime} 29.5^{\prime \prime}$ & $29^{\circ} 14^{\prime} 21.2^{\prime \prime}$ & ICP-OES, FAAS, FI \\
\hline Layered magnetite ore & LM7 & $54^{\circ} 39^{\prime} 40.3^{\prime \prime}$ & $29^{\circ} 14^{\prime} 21.3^{\prime \prime}$ & ICP-OES, FAAS, FI \\
\hline Layered magnetite ore & LM8 & $54^{\circ} 39^{\prime} 27.6^{\prime \prime}$ & $29^{\circ} 14^{\prime} 16.4^{\prime \prime}$ & ICP-OES, FAAS, FI \\
\hline Layered magnetite ore & LM9 & $54^{\circ} 39^{\prime} 29.5^{\prime \prime}$ & $29^{\circ} 14^{\prime} 21.2^{\prime \prime}$ & ICP-MS, ICP-OES, FAAS \\
\hline Layered magnetite ore & LM10 & $54^{\circ} 39^{\prime} 21.1^{\prime \prime}$ & $29^{\circ} 14^{\prime} 08.2^{\prime \prime}$ & ICP-MS, ICP-OES, FAAS \\
\hline Layered magnetite ore & LM11 & $54^{\circ} 39^{\prime} 29.3^{\prime \prime}$ & $29^{\circ} 13^{\prime} 57.7^{\prime \prime}$ & ICP-MS, ICP-OES, FAAS \\
\hline Fresh dolomitic marble & FM 1 & $54^{\circ} 39^{\prime} 40.0^{\prime \prime}$ & $29^{\circ} 14^{\prime} 21.7^{\prime \prime}$ & ICP-MS, ICP-OES, FAAS \\
\hline Fresh dolomitic marble & FM 2 & $54^{\circ} 40^{\prime} 00.0^{\prime \prime}$ & $29^{\circ} 14^{\prime} 24.5^{\prime \prime}$ & ICP-MS, ICP-OES, FAAS \\
\hline Fresh dolomitic marble & FM 3 & $54^{\circ} 39^{\prime} 33.5^{\prime \prime}$ & $29^{\circ} 13^{\prime} 59.0^{\prime \prime}$ & ICP-MS, ICP-OES, FAAS \\
\hline Fresh dolomitic marble & FM 4 & $54^{\circ} 39^{\prime} 31.2^{\prime \prime}$ & $29^{\circ} 14^{\prime} 22.0^{\prime \prime}$ & ICP-MS, ICP-OES, FAAS \\
\hline Fresh dolomitic marble & FM 5 & $54^{\circ} 39^{\prime} 37.9^{\prime \prime}$ & $29^{\circ} 14^{\prime} 0.04^{\prime \prime}$ & ICP-MS, ICP-OES, FAAS \\
\hline Altered dolomitic marble & AM 1 & $54^{\circ} 40^{\prime} 20.4^{\prime \prime}$ & $29^{\circ} 14^{\prime} 11.3^{\prime \prime}$ & ICP-MS, ICP-OES, FAAS \\
\hline Altered dolomitic marble & AM 2 & $54^{\circ} 39^{\prime} 38.0^{\prime \prime}$ & $29^{\circ} 14^{\prime} 00.6^{\prime \prime}$ & ICP-MS, ICP-OES, FAAS \\
\hline Altered dolomitic marble & AM 3 & $54^{\circ} 35^{\prime} 30.0^{\prime \prime}$ & $29^{\circ} 16^{\prime} 21.7^{\prime \prime}$ & ICP-MS, ICP-OES, FAAS \\
\hline Altered dolomitic marble & AM 4 & $54^{\circ} 35^{\prime} 36.2^{\prime \prime}$ & $29^{\circ} 16^{\prime} 29.0^{\prime \prime}$ & ICP-MS, ICP-OES, FAAS \\
\hline Altered dolomitic marble & AM 5 & $54^{\circ} 35^{\prime} 42.0^{\prime \prime}$ & $29^{\circ} 16^{\prime} 11.1^{\prime \prime}$ & ICP-MS, ICP-OES, FAAS \\
\hline Altered dolomitic marble & AM 6 & $54^{\circ} 35^{\prime} 39.0^{\prime \prime}$ & $29^{\circ} 16^{\prime} 22.0^{\prime \prime}$ & ICP-MS, ICP-OES, FAAS \\
\hline Altered dolomitic marble & AM 7 & $54^{\circ} 39^{\prime} 40.1^{\prime \prime}$ & $29^{\circ} 14^{\prime} 21.8^{\prime \prime}$ & ICP-MS, ICP-OES, FAAS \\
\hline Altered dolomitic marble & AM 8 & $54^{\circ} 39^{\prime} 29.5^{\prime \prime}$ & $29^{\circ} 14^{\prime} 21.2^{\prime \prime}$ & ICP-MS, ICP-OES, FAAS \\
\hline
\end{tabular}


TABle 1: Continued.

\begin{tabular}{lcccc}
\hline Sample & Field number & Easting & Northing & Type of analysis \\
\hline Altered dolomitic marble & AM 9 & $54^{\circ} 40^{\prime} 32.7^{\prime \prime}$ & $29^{\circ} 14^{\prime} 13.6^{\prime \prime}$ & ICP-MS, ICP-OES, FAAS \\
Altered dolomitic marble & AM 10 & $54^{\circ} 39^{\prime} 40.3^{\prime \prime}$ & $29^{\circ} 14^{\prime} 11.0^{\prime \prime}$ & ICP-MS, ICP-OES, FAAS \\
Altered dolomitic marble & AM 11 & $54^{\circ} 36^{\prime} 20.6^{\prime \prime}$ & $29^{\circ} 15^{\prime} 30.8^{\prime \prime}$ & ICP-MS, ICP-OES, FAAS \\
\hline
\end{tabular}

ICP-MS = inductively coupled plasma mass spectrometry, NICP-OES = inductively coupled plasma optical emission spectroscopy, FAAS = flame atomic absorption spectrophotometry, and FI = fluid inclusion.

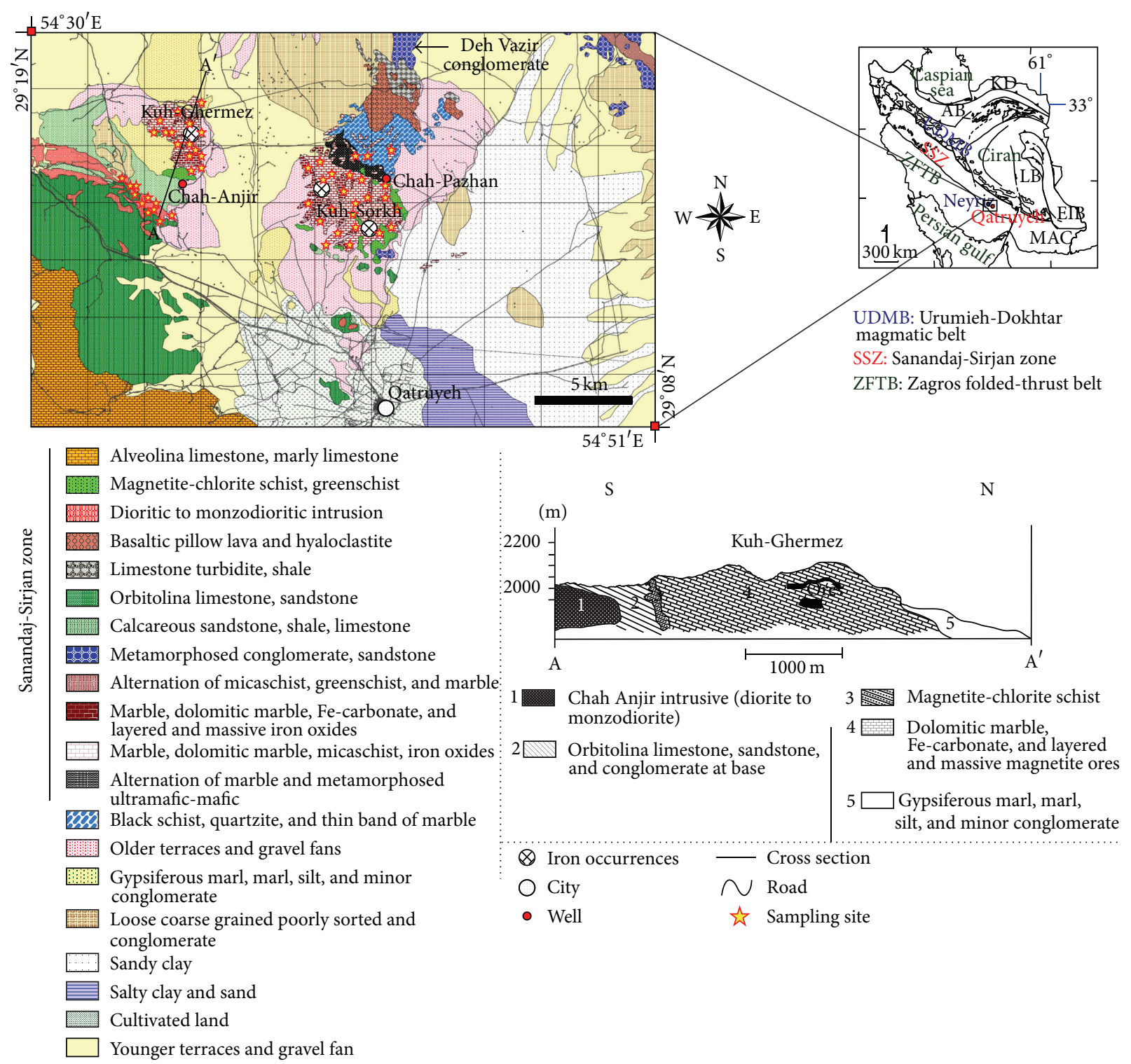

FIGURE 1: Schematic geological map of the Qatruyeh area and tectonic scheme of Iran and interpretative cross section A-A' from south to north.

high-resolution ion microprobe (SHRIMP) U-Pb and monazite chemical Th-U-total $\mathrm{Pb}$ isochron methods (CHIME) presumably regional metamorphic event occurred between $187 \pm 2.6 \mathrm{Ma}$ and $180 \pm 21 \mathrm{Ma}$, respectively. These rocks experienced clockwise $P-T$ path and thrusted into the imbricate slices during exhumation [48]. The amphibolite facies metamorphism in early Cimmerian orogeny could be correlated with the regional $\mathrm{D}_{1}$ deformation. Exhumation of the metamorphic complexes and the resultant cooling and decompression of the metamorphic rocks followed by development of postearly Cimmerian sedimentary basins occurred in a transpressive regime due to subduction of the Neotethys. As a result, calc-alkaline mafic to felsic intrusive rocks were emplaced in the northeastern part of the region. A high-pressure-low-temperature metamorphic belt was formed during the first stage of the deformation. 


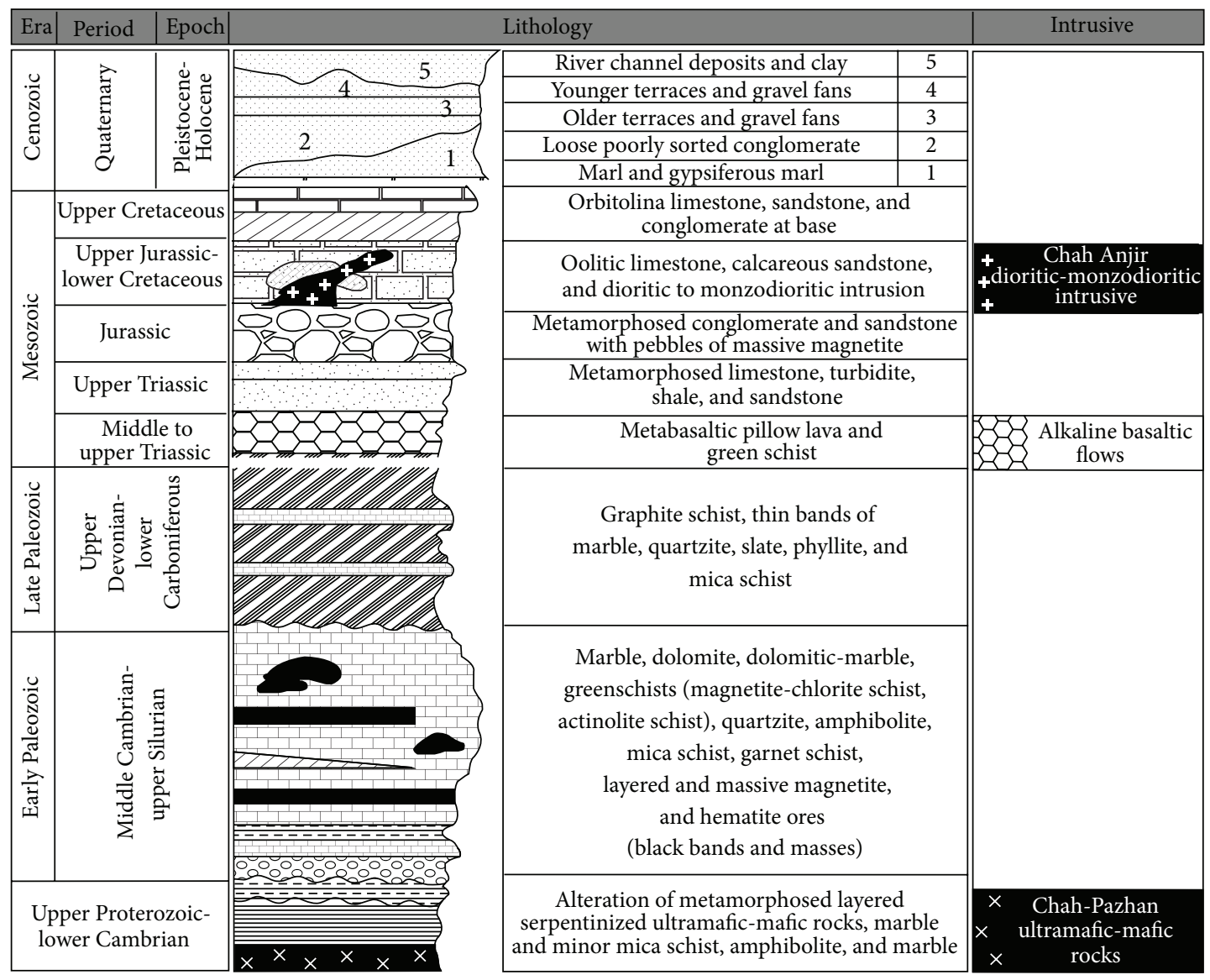

FIGURE 2: Summarized schematic lithostratigraphic column in the Qatruyeh area.

The result of this deformation is a composite foliation between massive magnetite and dolomitic marble that occurred along a wide ductile shear zone [40].

The $\mathrm{D}_{2}$ deformation is associated with overthrusting of the old units (e.g., the Chah Pazhan ultramafic-mafic rocks) onto the Qatruyeh metacarbonate unit and the development of a mylonitic foliation in the various rocks units. Veinlets of iron oxides display pinch and swell features along the foliation. These relationships indicate that percolating fluids moved through permeable zones of foliation. The resulting boudinage show that ductile deformation went on after formation of iron oxides (hematite) and dolomitic-marble host rock (Figure 3(b)).

Whereas $\mathrm{D}_{1}$ and $\mathrm{D}_{2}$ developed under amphibolite and greenschist facies metamorphic conditions, $\mathrm{D}_{3}$ represents an event leading to the development of kink bands, localized shear zones, and slickensides along the thrust sheet of the Qatruyeh area [47]. Abundant kink bands of several centimeter thicknesses overprinted all other deformation structures such as both magnetite and hematite ores.

\section{Ore Bodies' Geology}

There are twelve ore bodies in the Qatruyeh area. KuhSorkh and Kuh-Ghermez were chosen for detailed field investigation, petrography, and chemical analyses. Both ore bodies occur within the metasedimentary rocks of the early Paleozoic which consists predominantly of dolomitic limestone, greenschist, and quartzite (group B). The iron oxide ores can be divided into massive and layered magnetite ores with minor hematite. The ore bodies were not exploited due to their low tonnages in the area.

The massive magnetite ore bodies are often in contact with micaschist and dolomitic marble. They occurred often as very small sized masses with maximum $5 \mathrm{~m}^{2}$ area which replaced metacarbonates. The ore bodies have variable orientation and shape and commonly have been fractured and cut by quartz-bearing hematite veins. The layered magnetite ores, however, have few centimeters to several meters width $(>10 \mathrm{~m})$ and are found throughout the area interbedded with the stratified metacarbonate rocks (Figure 3(c)). These host rocks were strongly affected by sodic-calcic alteration. These sodic-calcic alteration zones are spatially associated with layered magnetite bodies that appear to have replaced marbles, dolomitic marbles, and chlorite-schist rocks. Pervasive sodic-calcic alteration grades into zones of layered, actinolite crystals intergrown with magnetite. Most intense sodic-calcic alteration is dominated by pervasive rock replacement by siderite + paragonite with associated layered magnetite ores. The ores are most often horizontal to subhorizontal and elongated WNW-ESE trending, concordant with the regional structures. 


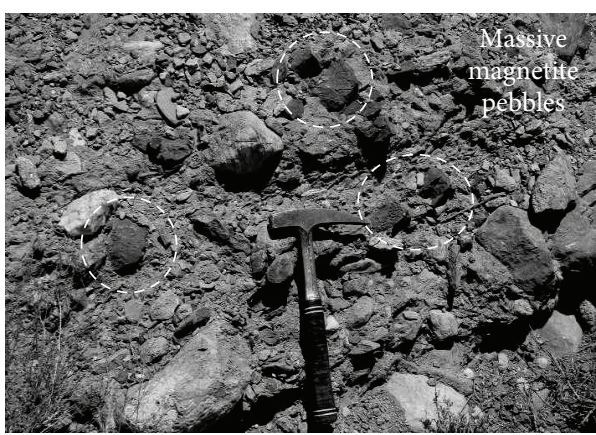

(a)

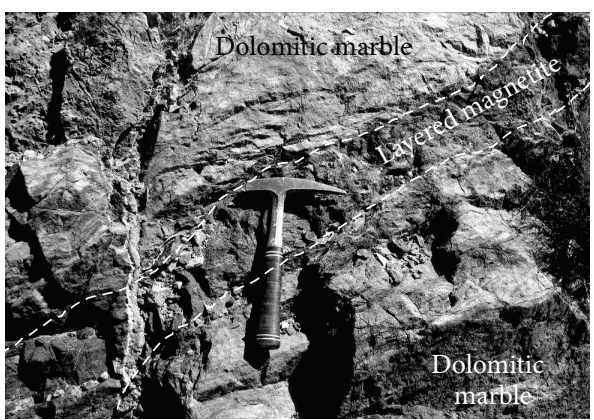

(c)

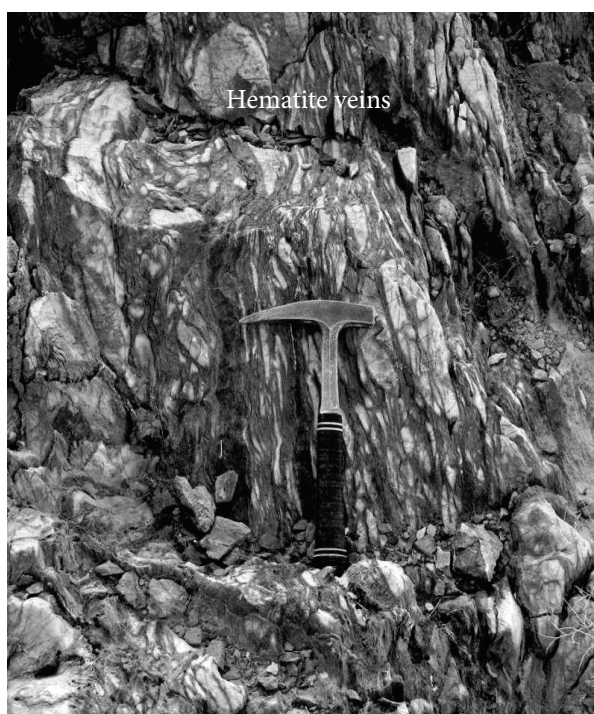

(e)

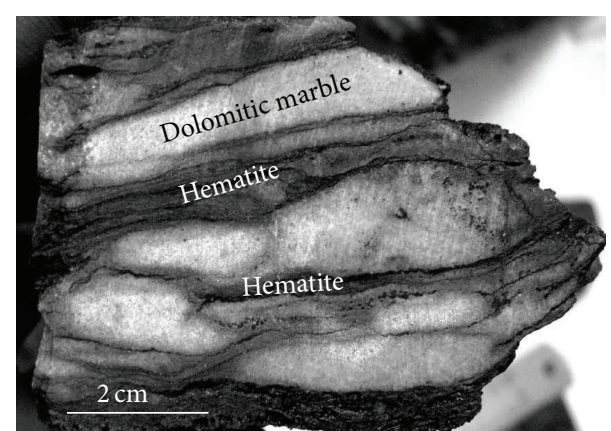

(b)

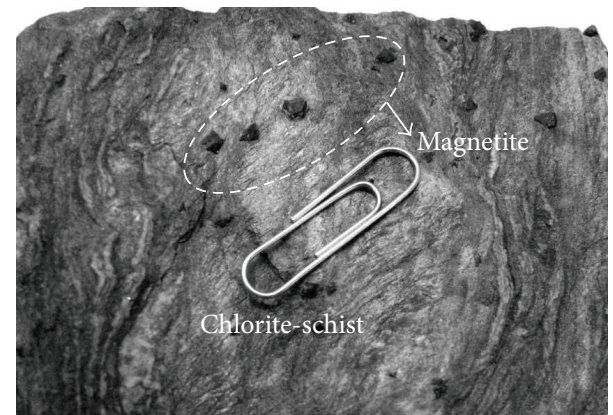

(d)

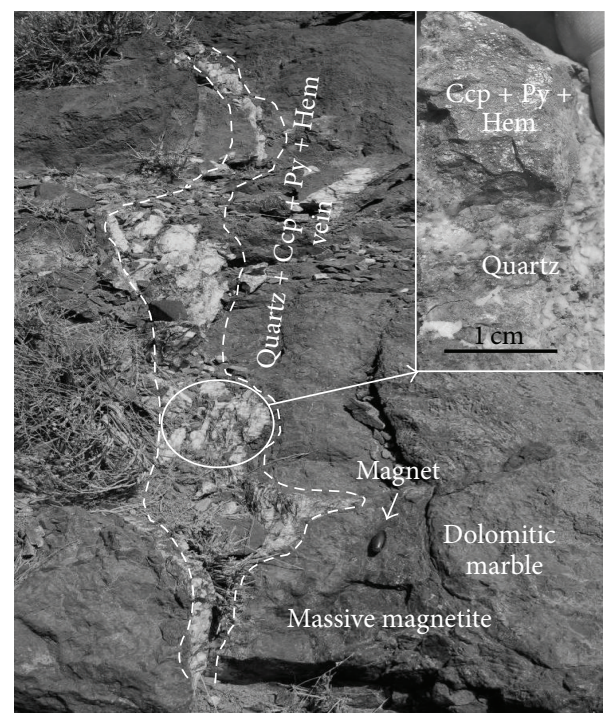

(f)

FIGURE 3: Photographs illustrating aspects of structures in the magnetite-hematite ores and host rock. (a) Massive magnetite pebbles within the Jurassic Deh Vazir conglomerate, (b) rhythmic banding and boudinage deformation of hematite and marble, (c) layered magnetite within dolomitic marble, (d) disseminated magnetite mineralization in chlorite-schist (magnetite chlorite-schist), (e) hematite veins with a mylonitic structure show evidence for strong ductile deformation, (f) quartz + pyrite \pm chalcopyrite \pm hematite secondary veins cut dolomitic marble and massive magnetite. Magnet size: $3 \mathrm{~cm}$. (f) Mineral abbreviations: $\mathrm{Ccp}=$ chalcopyrite, $\mathrm{Hem}=\mathrm{hematite}$, and Py $=$ pyrite.

Minor disseminated subhedral to euhedral magnetites are common in the area, dominantly appears in chlorite-schist (Figure 3(d)). Minor hematite occurrences are found in the upper parts of the brecciated and mylonitized metacarbonates (Figure 3(e)) that display propylitic alteration near the fault contact.
The metacarbonates and chlorite-schists adjacent to intrusive rocks (intrusions) are crossed by later veins of hematite + quartz \pm pyrite \pm chalcopyrite (Figure $3(f)$ ). Such veins are generally poorly mineralized and appear to represent a late, high-level zone of hydrothermal alteration. 


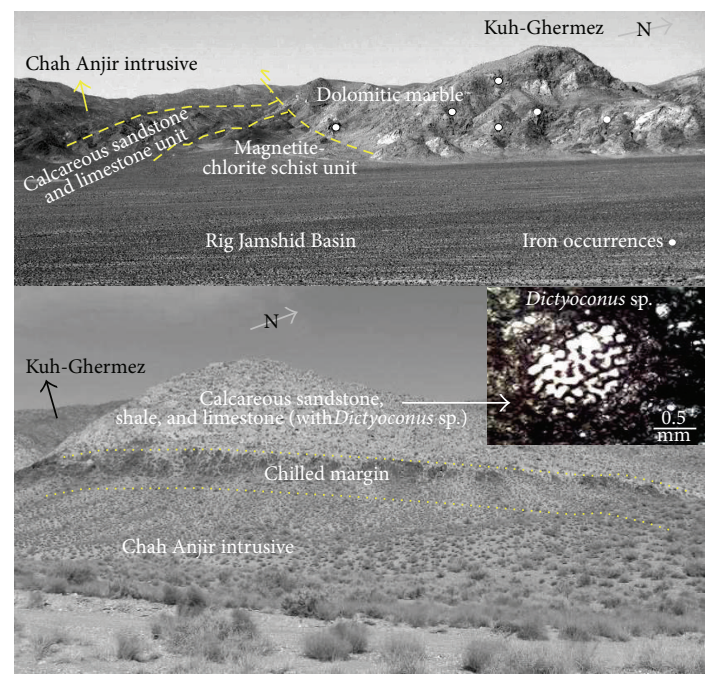

(a)

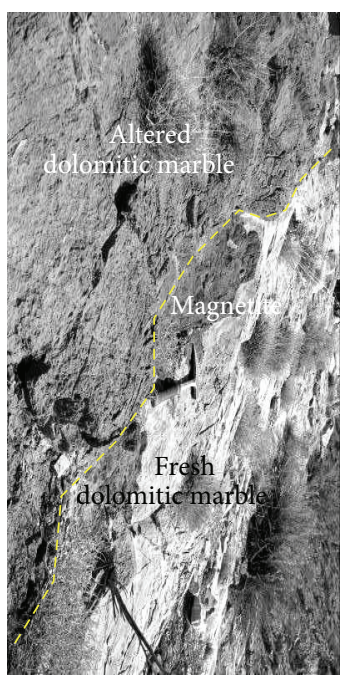

(b)

FIgURE 4: (a) Panorama photograph of the Chah Anjir intrusive unit, chilled margin and calcareous sandstone, and shale unit with Dictyoconous sp. fossil, (b) comparison between fresh and altered dolomitic marble.

\section{Petrography}

The metamorphic rocks are extensively formed in the Qatruyeh area which is composed of metacarbonate rocks (marble and dolomitic marble), chlorite-schist, micaschist, and metagabbroic schist with small amounts of amphibolite. A heterogeneous intrusion with about $1 \mathrm{~km}$ in diameter is located in the south of the area showing a chilled margin. It has been emplaced within the calcareous sandstone and shale whose Dictyoconous sp. microfossils indicate late Jurassic to early Cretaceous age (Figure 4(a)). The plutonic rocks range from dioritic to monzodioritic in composition.

The dolomitic-marble rocks appear white (fresh) to yellowish-brown (altered) in color due to the absence or presence of siderite, respectively (Figure 4(b)). The rocks are considered to be extensively replaced by magnetite and hematite. The rhythmic banding in dark altered and light colored fresh rocks is easily distinguished in the field.

Microscopic observations indicate several replacement textures due to alteration. These include widening of a fracture filling where a fracture crosses a chemically reactive rock (Figure 5(a)), irregular or vermicular intergrowths of hematite and calcite-dolomite (Figure 5(b)), remnant islands of nonreplaced host rock, rims of one mineral penetrating another along its crystallographic directions (Figure 5(c)), nonmatching walls or borders of a fracture, and cusp and caries textures (Figure 5(d)) [49].

\section{Alteration and Mineral Assemblages}

Metasomatism accompanied by intrusions, and/or metamorphism, may be responsible for iron oxide mineralization in the Qatruyeh area. Microscopic observations and X-ray diffraction patterns on ore samples and metacarbonates have led to the recognition of two main alteration stages in the layered magnetite- and hematite-bearing ores (Table 2).
The first stage of alteration includes $\mathrm{Na}-\mathrm{Ca}$ metasomatism (actinolite + titanite + epidote + calcite + albite \pm scapolite \pm quartz), which is characteristic of diorite-monzodiorite plutonic rocks (Figure 6(a)). Epidote and actinolite replaced plagioclase; magnetite inclusions were found in some actinolites (Figure 6(b)). Magnetite, actinolite, tremolite, tourmaline, titanite, and quartz are the major minerals; pyrite and chalcopyrite occur as minor phases in the accompanying layered ore bodies (Figure 6(c)). Layered magnetite ores replaced dolomitic marble and the calc-silicate minerals that are typical of skarns are virtually absent from the ore zones [50]. Paragonite and siderite are exclusively identified within the halos of $1-3 \mathrm{~m}$ in diameter close to ore bodies that were only recorded at XRD data. Paragonite was formed during the early metasomatic stage. The same data records were observed in Lena Gold District, Siberia [51]. Siderite is produced by replacement of calcite or dolomite by an iron-rich solution [52] and paragonite is formed by solutions during regional metamorphism [51].

The second stage of alteration is shown by hematitization in brecciated metacarbonate (Figure 6(d)). Hydrothermal activity has produced a specific alteration around hematite ores, with a more regionally developed propylitic zone. This alteration style is very common in hematite ores and indicates the activity of a volatile-rich hydrothermal solution [6]. The alteration that is associated with oxidizing fluids often results in the formation of minerals with a high $\mathrm{Fe}^{3+} / \mathrm{Fe}^{2+}$ ratio and, in particular, hematite associated with sericite + quartz + epidote + chlorite \pm magnetite [53]. Hematite + quartz \pm pyrite \pm chalcopyrite veins accompanied the late stage of each main ore mineralization in the Qatruyeh area.

\section{Results}

8.1. Geochemistry. In order to study the major, trace, and REE compositions of the Chah Anjir plutonic rocks, eleven 


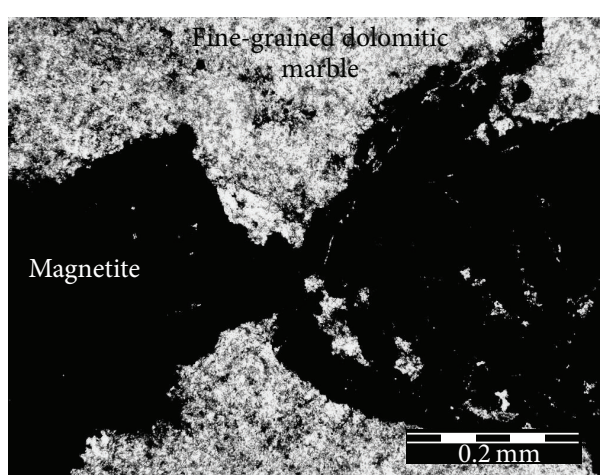

(a)

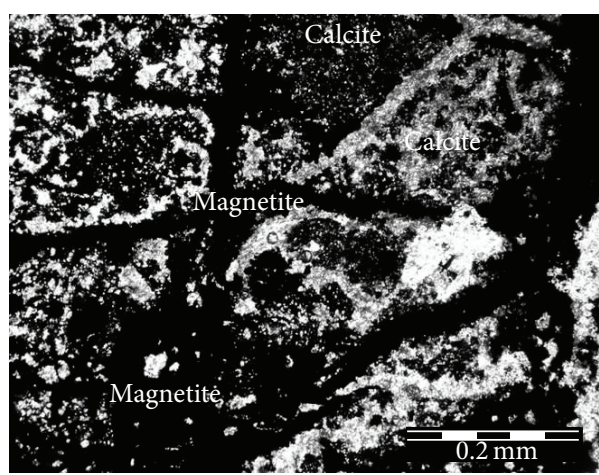

(c)

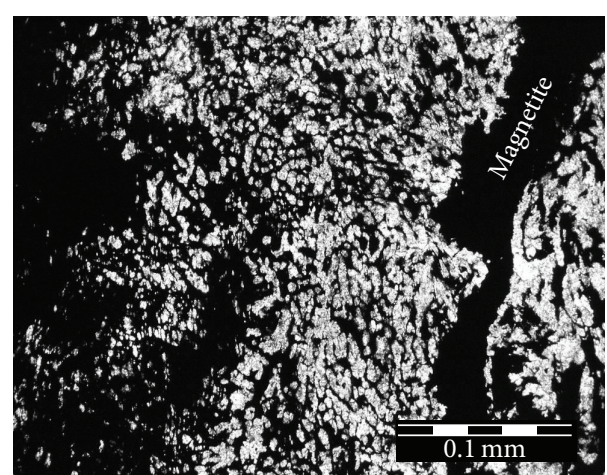

(b)

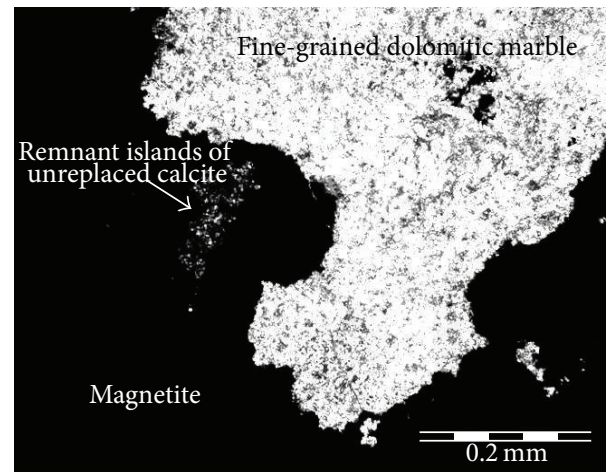

(d)

FIGURE 5: Replacement textures in magnetite-hematite and host rock (all photomicrographs have been taken in transmitted light). (a) Widening of a fracture filling where the fracture crosses a chemically reactive rock, (b) irregular or vermicular intergrowths, (c) rims of one mineral penetrating another along its crystallographic direction, and (d) concave surface into the host or cusp and caries texture and remnant islands of the replaced host.

TABLE 2: Generalized paragenetic sequence in the Qatruyeh area.

\begin{tabular}{|c|c|c|c|c|}
\hline & \multirow{2}{*}{ Premetamorphic and syn-metamorphic } & \multicolumn{3}{|c|}{ Postmetamorphic } \\
\hline & & $\mathrm{Na}-\mathrm{Ca}$ alteration & Propylitic alteration & Oxidation \\
\hline Massive magnetite & - & & & \\
\hline Layered magnetite & & - & $\cdots$ & \\
\hline Hematite & & $\cdots$ & - & - \\
\hline Tourmaline & & $\cdots$ & & \\
\hline Titanite & & - & $\cdots$ & \\
\hline Scapolite & & - & & \\
\hline Actinolite & & - & $\ldots$ & \\
\hline Siderite & & - & & \\
\hline Paragonite & & - & & \\
\hline Epidote & & & - & \\
\hline Sericite & & & - & \\
\hline Chlorite & & & - & \\
\hline Quartz & $\cdots$ & $\cdots$ & - & $\cdots$ \\
\hline Pyrite & & $\cdots$ & $\cdots$ & \\
\hline Chalcopyrite & & $\cdots$ & $\cdots$ & \\
\hline Calcite & - & $\cdots$ & $\ldots$ & \\
\hline Dolomite & - & $\ldots$ & $\ldots$ & \\
\hline Goethite & & & & $\cdots$ \\
\hline Limonite & & & & $\ldots$ \\
\hline Malachite & & & & $\cdots$ \\
\hline
\end{tabular}

-Major phase, $\cdots$ Minor phase. 


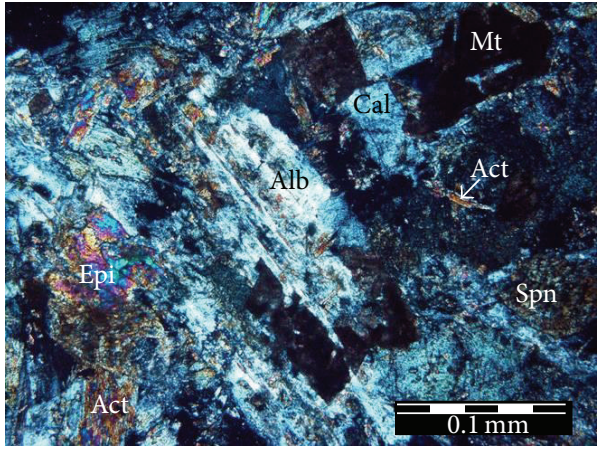

(a)

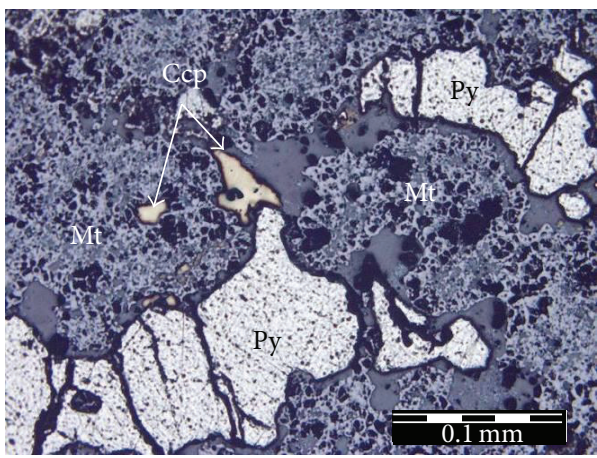

(c)

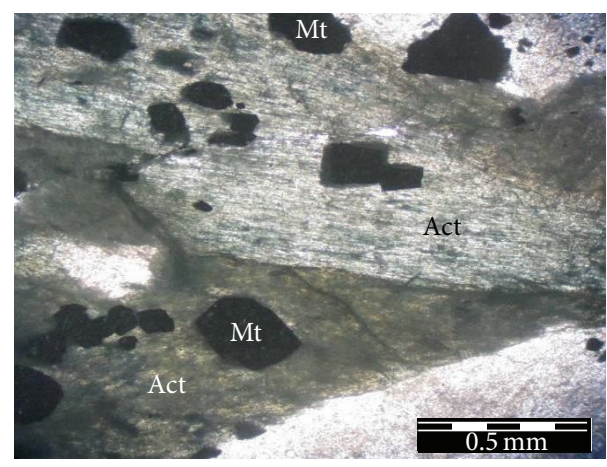

(b)

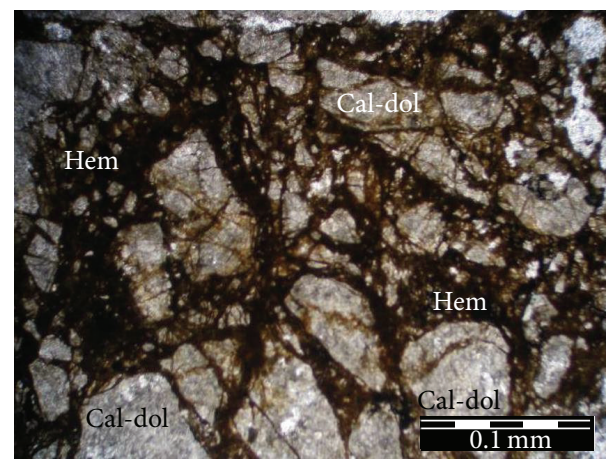

(d)

Figure 6: (a) Mineral assemblages of Na-Ca metasomatism in plutonic rocks. Albite + titanite + epidote + actinolite + calcite + magnetite (XPL), (b) magnetite mineralization is contemporaneous with the main phase of actinolitization (PPL), (c) chalcopyrite and pyrite as a late phase with magnetite (sulfides minerals include inclusion of magnetite) (RL), (d) a host-breccia (cataclastic texture), crashed calcite with hematite matrix (PPL). Mineral abbreviations: Act $=$ actinolite, $\mathrm{Alb}=$ albite, $\mathrm{Cal}=$ calcite, $\mathrm{Cal}-\mathrm{Dol}=$ calcite and dolomite, $\mathrm{Ccp}=\mathrm{chalcopyrite}$, Epi $=$ epidote, $\mathrm{Mt}=$ magnetite, $\mathrm{Py}=$ pyrite, and $\mathrm{Spn}=$ sphene.

samples were collected from surficial exposures. The emphasis during sampling was on fresh rocks, so as to avoid metasomatic changes during hydrothermal alteration.

Results of the whole rocks chemical analyses of major, trace, and REE in the Chah Anjir migmatite are summarized in Table 3. According to $R_{1}-R_{2}$ discrimination diagram [26] and the classification diagram for plutonic rocks [28], the Chah Anjir intrusive rocks can be classified as diorite, monzodiorite (Figure 7(a)), and diorite to syenodiorite, respectively (Figure 7(b)), with subalkaline to alkaline affinity (Figure 8(a)). As indicated in Figure 8(b), the plutonic rocks plot within the calc-alkaline to tholeiitic fields. In order to determine the tectonic setting for the plutonic rocks and its relation to ore mineralization, $\mathrm{Y}-\mathrm{Nb}$ and $(\mathrm{Y}+\mathrm{Nb})-\mathrm{Rb}$ diagrams [30] were used. On the $\mathrm{Y}-\mathrm{Nb}$ diagram, the samples plot in the volcanic arc to syn-collisional granite fields (Figure $8(\mathrm{c}))$. On the $\mathrm{Rb}-(\mathrm{Y}+\mathrm{Nb})$ diagram the samples fall in the field of volcanic arc granitoids (Figure $8(\mathrm{~d})$ ). The tectonic setting is confirmed to geological characteristics of the Qatruyeh area.

In the A-B diagram of [31], the samples show a negative slope in IV sectors of metaaluminous area that is such a trend characteristic of cafemic (CAFEM) rocks due to presence of hornblende, ortho- and clinopyroxene, biotite, epidote, and titanite in origin (Figure 9(a)). According to the A/CNK $<1.1$ ratio [54] and $\mathrm{Zn}$ versus $\mathrm{SiO}_{2}$ diagrams (Figure 9(b)) [32] and $\mathrm{SiO}_{2}-\mathrm{Fe}_{2} \mathrm{O}_{3} / \mathrm{FeO}$ diagram [33] the Qatruyeh plutonic rocks are considered I-type and magnetite series granitoids (Figure 9(c)). These results associated with those of the intrusions fall in the hydrothermal iron deposits field.

REEs from the samples were normalized to chondrites using the values of Wakita et al. [55]. Enrichment coefficients of $\mathrm{La}\left((\mathrm{La} / \mathrm{Sm})_{\mathrm{CN}}\right), \mathrm{La}\left((\mathrm{La} / \mathrm{Lu})_{\mathrm{CN}}\right), \mathrm{Gd}\left((\mathrm{Gd} / \mathrm{Lu})_{\mathrm{CN}}\right)$, and $[\mathrm{Eu}] /\left[\mathrm{Eu}^{*}\right]$ as Eu anomaly were examined. The results indicate that the Chah Anjir intrusive rocks were enriched in light rare earth elements (LREEs) compared to heavy rare earth elements (HREEs) (Figure 9(d)). Moderate to negative Eu anomalies, high total REE contents $\left(\sum \mathrm{REE}=\right.$ 155-188 with average of 168), and high LREE/HREE ratios $\left((\mathrm{La} / \mathrm{Lu})_{\mathrm{CN}}=7.6-11\right)$ are also observed. These evidences suggest continental or continental-margin geological settings for the intrusive rocks in the Qatruyeh area. The negative Eu anomalies can be explained by the abundance of plagioclase feldspar in the melt. As proposed by Henderson [56], small amounts of garnet, amphibole, or pyroxene can reduce the HREE relative to LREE in the melt.

As mentioned, iron ores could be divided into high-grade magnetite ores (consisting of massive magnetite with minor silicate minerals) and low-grade magnetite ores (layered magnetite with silicate minerals) and hematite ores. The major, trace, and rare earth elements of the Qatruyeh iron oxide ores 


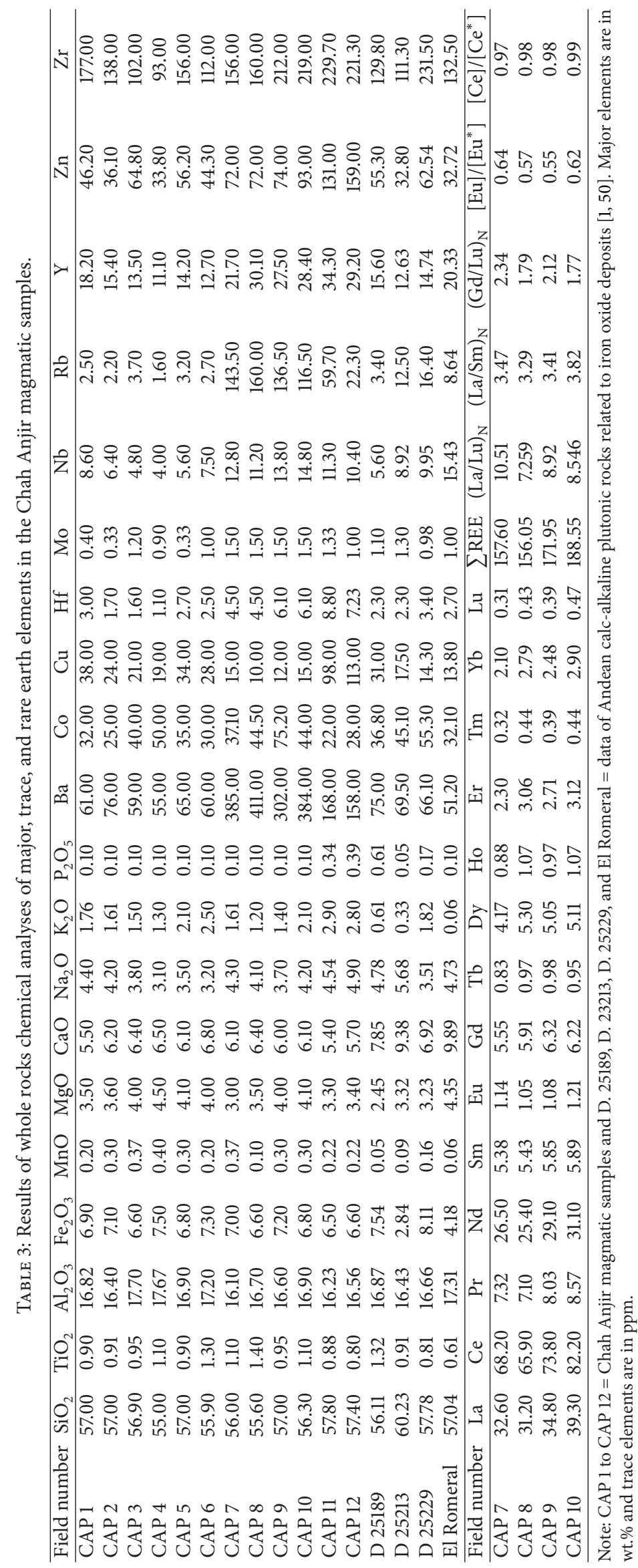




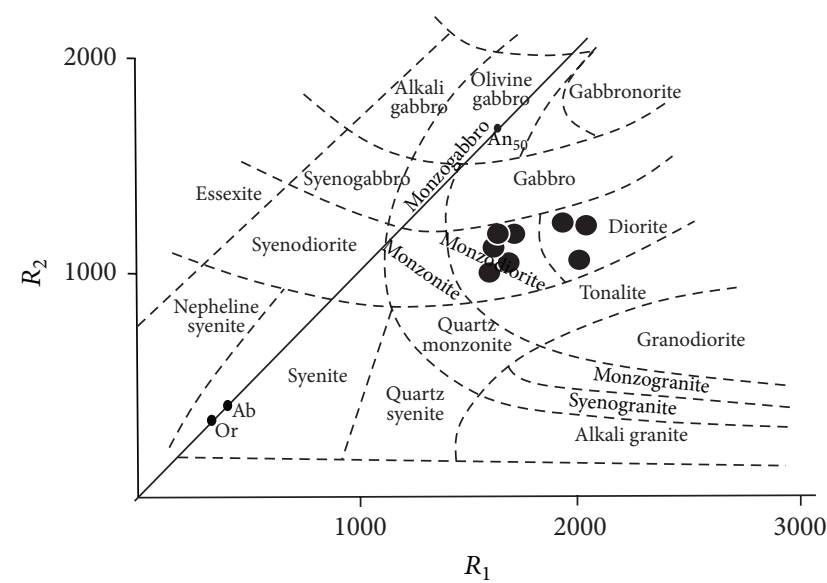

(a)

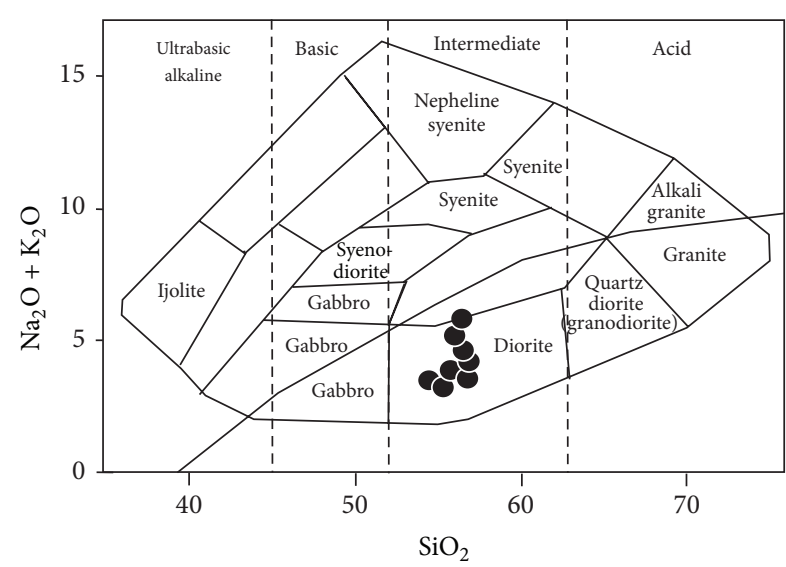

(b)

Figure 7: (a) The classification of plutonic rocks using the parameters $R_{1}-R_{2}$ [26]. Parameters are defined by the $R_{1}=[4 \mathrm{Si}-11(\mathrm{Na}+\mathrm{K})-$ $2(\mathrm{Fe}+\mathrm{Ti})]$ and $R_{2}=(\mathrm{Al}+2 \mathrm{Mg}+6 \mathrm{Ca})$ and $(\mathrm{b})$ the chemical classification of plutonic rocks using total alkaline versus $\mathrm{SiO}_{2}$ from [27] and modified by [28]. The analyzed samples were present as black circles.

are presented in Table 4 . The high-grade magnetite ores typically have high contents of $\mathrm{TiO}_{2}$ (0.09 to $\left.1.08 \mathrm{wt} . \%\right)$, whereas the low-grade ores indicate the high amounts $\mathrm{Na}_{2} \mathrm{O}+$ $\mathrm{K}_{2} \mathrm{O}$ (avg. 1.08 wt.\%) and $\mathrm{CaO}$ (avg. 3.8 wt.\%).

Enrichment of sulfur in the layered magnetite is reflected by the presence of sulfides such as pyrite and chalcopyrite. There are strong positive correlations among $\mathrm{Fe}_{2} \mathrm{O}_{3}, \mathrm{TiO}_{2}$ and HFSEs (Hf, Sc, Th, U, Nb, and $\mathrm{Zr}$ ), LREEs, and transition metals $(\mathrm{Cr}, \mathrm{Co}$, and $\mathrm{Ni}$ ) in layered magnetite. In contrast, the strong negative correlations between the two oxides with HREEs and LILEs $(\mathrm{Ba}, \mathrm{K}$, and $\mathrm{Rb})$ indicate that layered magnetite acts as a scavenger for HFSEs, LREEs, and intermediate elements (Figure 10). It was inferred that the relationship was due to the similarity of the behavior of those elements in spinel group minerals.

The positive correlation between LREEs and $\mathrm{Al}_{2} \mathrm{O}_{3}, \mathrm{CaO}$, $\mathrm{Na}_{2} \mathrm{O}$, and $\mathrm{MgO}$ indicate that the LREEs are collected in the silicate phases in the ore bodies.

High values of chalcophile elements $(\mathrm{Hg}, \mathrm{Bi}, \mathrm{Cu}$, and $\mathrm{Ag}$ ) were observed in layered magnetite as a below-ore halo and deep-seated iron mineralization.

The REE distribution patterns in high-grade massive magnetite and low-grade layered magnetite ores are very different (Figure 9(d)). These patterns can show differential origins of both ore bodies. An average $(\mathrm{La} / \mathrm{Lu})_{\mathrm{CN}}$ ratio of 6.3 in the layered ores indicates a high degree of fractionation. A weak negative Eu anomaly and LREE enrichment are observed in the layered magnetite. In contrast, high-grade ores are depleted in LREE, enriched in HREE, and display a strong negative Eu anomaly. The depleted LREE pattern is interpreted as high-temperature leaching of LREE or the occurrence of a lower temperature metamorphism [57]. It is suggested that Ce depletion in high-grade magnetite may be the result of a late stage metasomatic alteration in the Qatruyeh area. This indicates that the two ore occurrences, layered and massive, are different in origin.
The bulk compositions of the altered and fresh metacarbonates are given in Table 5. Altered rocks are depleted in $\mathrm{CaO}$ and $\mathrm{MgO}$ relative to fresh metacarbonate samples whereas the $\mathrm{Fe}_{2} \mathrm{O}_{3}, \mathrm{Al}_{2} \mathrm{O}_{3}, \mathrm{~K}_{2} \mathrm{O}$, and $\mathrm{Na}_{2} \mathrm{O}$ contents increased in the rocks during metasomatic alteration. An increase in the $\mathrm{K}_{2} \mathrm{O}$ and $\mathrm{Al}_{2} \mathrm{O}_{3}$ contents is the result of muscovite abundance in the altered rocks. $\mathrm{TiO}_{2}, \mathrm{Ba}, \mathrm{Rb}, \mathrm{Cr}$, and $\mathrm{V}$ can also be present within muscovite. The difference in the position of data points of altered and fresh rocks is explained in Figure 11.

High $\mathrm{MnO}$ and $\mathrm{Fe}_{2} \mathrm{O}_{3}$ values in altered dolomitic marbles indicate that $\mathrm{Fe}$ and $\mathrm{Mn}$ replace $\mathrm{Mg}$ in dolomite lattice. In order to evaluate the compositional change which accompanies hydrothermal alteration, the concentrations of elements of interest are compared to those of immobile elements such as Zirconium. Typically, $\mathrm{Zr}$ is used as immobile and incompatible element during hydrothermal alteration due to the very high ionic radius [58]. In the case of chemically incompatible elements, the regression lines REEs and HFSEs which are considered to be immobile with each other in the Qatruyeh altered dolomitic marbles (Figures 12(a)-12(d)). The REEs are less well correlated with the above HFSEs and the regression lines shift from the origin, which suggests that the REEs were somewhat mobile during alteration. The interelement correlation among the REEs is significant (generally with coefficients higher than 0.7), which is consistent with their similar geochemical behavior. However, the interelement correlation among LREEs and HREEs treated separately is considerably stronger, which indicates fractionation between the two subgroups. LILEs ( $\mathrm{Ba}, \mathrm{Sr}, \mathrm{Rb}$, and $\mathrm{Cs}$ ) are more mobile relative to $\mathrm{Zr}$ during hydrothermal alteration as shown by their poor correlations in Figures 12(e) and 12(f).

8.2. Fluid Inclusions Study. Microthermometric measurements were made using a Linkam THMSG600 combined heating and freezing stage with a temperature range of 


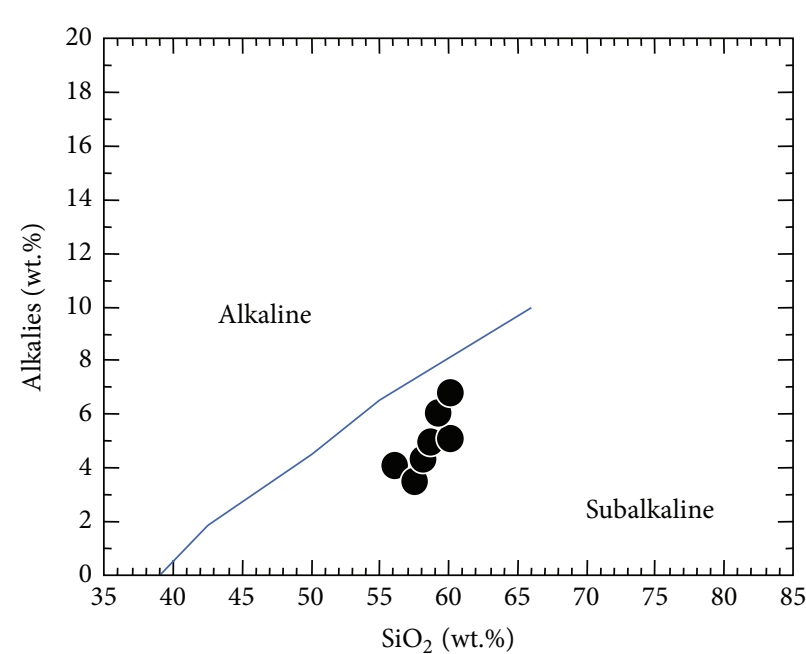

(a)

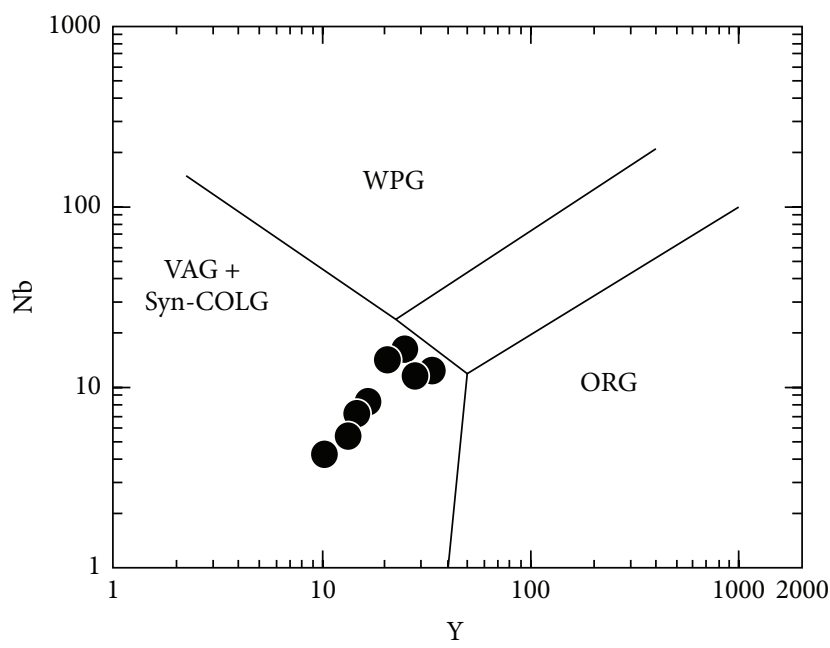

(c)

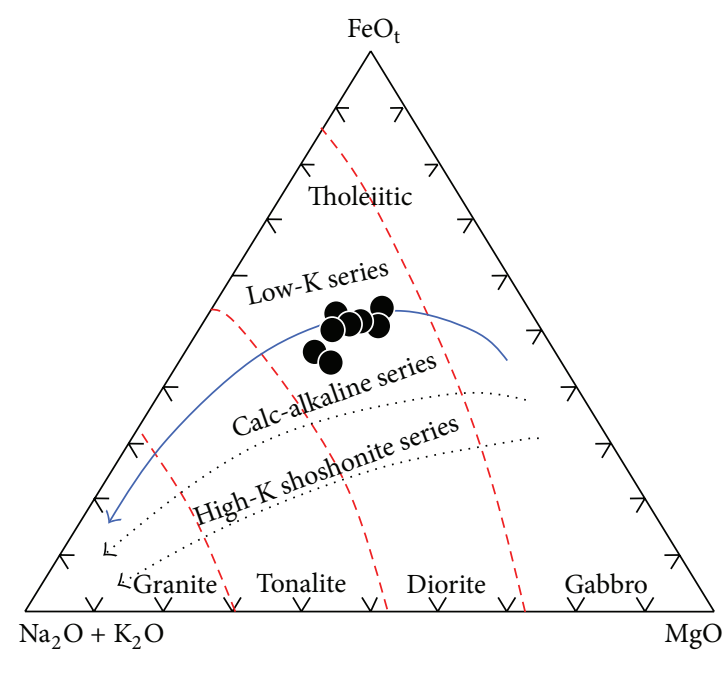

(b)

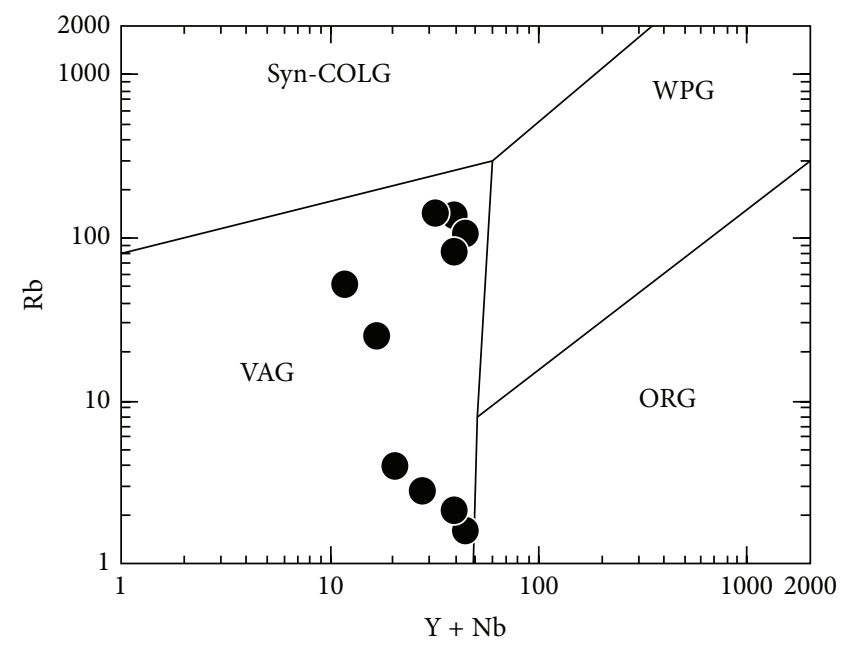

(d)

FIGURE 8: (a) alkali-silica diagram for determining subalkaline and alkaline fields [29], (b) AFM diagram for determining submagma type (tholeiitic or calc-alkaline), (c) and (d) position of the Chah Anjir samples on $\mathrm{Y}$ versus $\mathrm{Nb}$ and $\mathrm{Rb}$ versus $\mathrm{Y}+\mathrm{Nb}$ diagrams [30]. Abbreviations: $\mathrm{AFM}=$ alkaline components $\left(\mathrm{Na}_{2} \mathrm{O}+\mathrm{K}_{2} \mathrm{O}\right)-\mathrm{FeO}_{\text {total }}-\mathrm{MgO}, \mathrm{ORG}=$ ocean ridge granites, Syn-COLG $=$ syn-collision granites, VAG + Syn$\mathrm{COLG}=$ volcanic arc granites + syn-collision granites, and VAG $=$ volcanic arc granites. The analyzed samples were presents as black circles.

-196 to $+600^{\circ} \mathrm{C}$ and a reproducibility of $\pm 0.1^{\circ} \mathrm{C}$, at the fluid research laboratory at the Geological Survey of Iran by optical microscopy and microthermometry, attached to an Olympus petrographic microscope with LinkSys software (version 1.83). Ten doubly polished quartz wafers were prepared using the procedure of Shepherd et al. [59]. The thickness of the wafers varied between 150 and $300 \mu \mathrm{m}$, depending upon the transparency of the quartz crystals. Sample selection was biased to quartz containing an abundance of $\mathrm{Na}-\mathrm{Ca}$ minerals in low-grade magnetite type. The fluid inclusions have a variety of shapes (mainly rounded, elongate, or square and, less commonly, irregular) and typically are of low to medium size (5 to $50 \mu \mathrm{m})$. Quartz in the samples contains inclusions $>10 \mu \mathrm{m}$ which allows for more confident thermometric analysis. Based on petrographic and microthermometric studies and present phases at temperature room, inclusions are divided into the following types (Figures 13(a)-13(d)).

(1) Two-phase liquid + vapor (type A), (2) three-phase vapor + liquid $\left(\mathrm{L}_{1}\right)+\mathrm{CO}_{2}$ liquid $\left(\mathrm{L}_{2}\right)$ (type $\left.\mathrm{B}\right),(3)$ monophase liquid (type $\mathrm{C}$ ), and (4) monophase vapor (type $\mathrm{D}$ ). Types $\mathrm{A}$ and $\mathrm{B}$ constitute the majority of fluid inclusions in the Qatruyeh quartz veins (proximal to the Chah Anjir intrusive unit) and account for $80 \%$ of the inclusion population and were chosen for microthermometric studies for two important reasons: (1) the inclusions are mostly intimately associated with layered magnetite mineralization, (2) these types contain inclusions $>5 \mu \mathrm{m}$ which allows for more confident thermometric analysis. In addition, primary fluid inclusions, with no evidence of necking down, were selected for microthermometric analyses. 


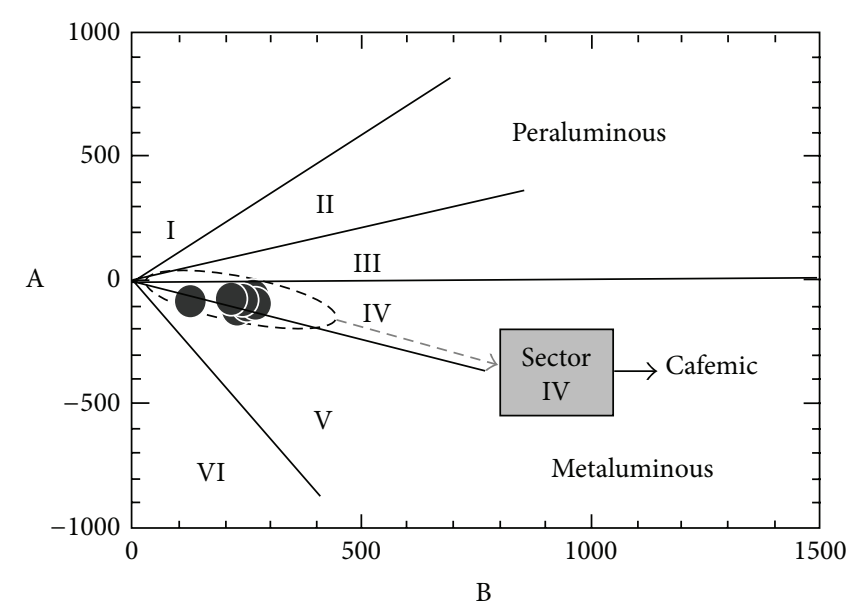

(a)

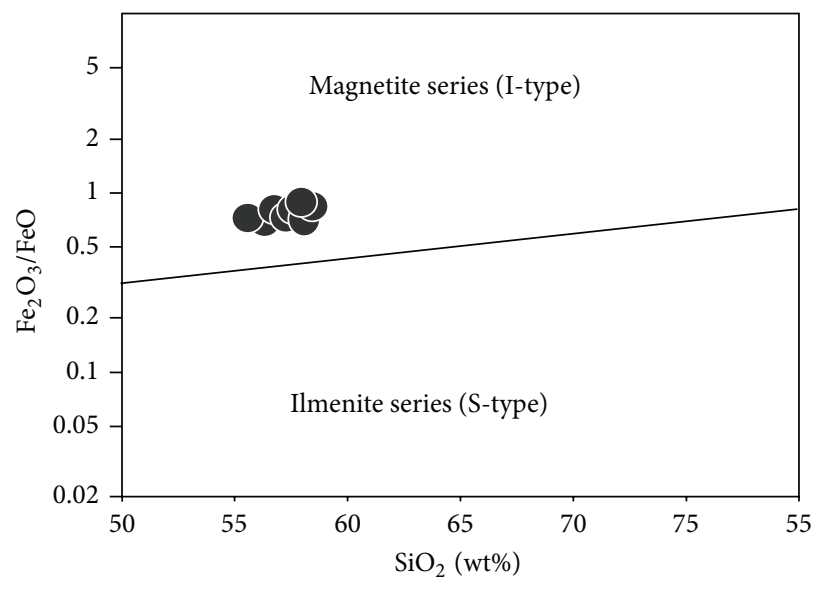

(c)

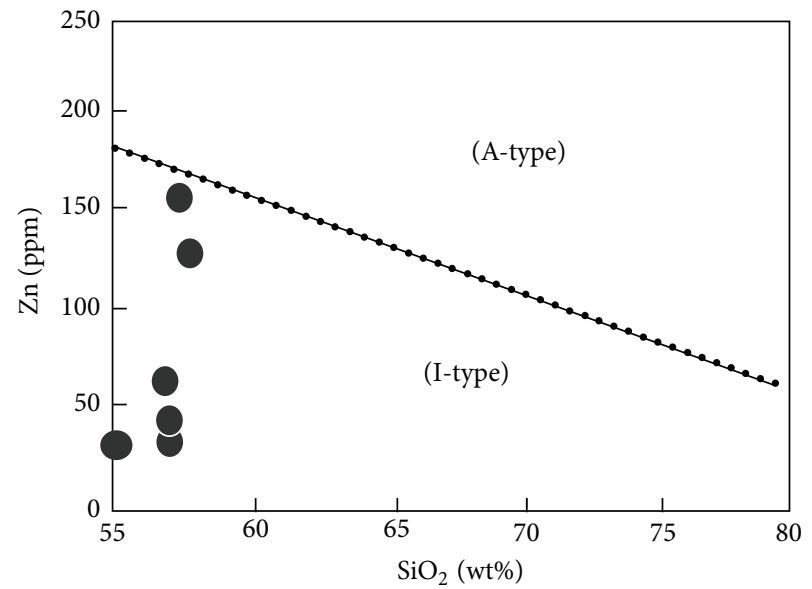

(b)

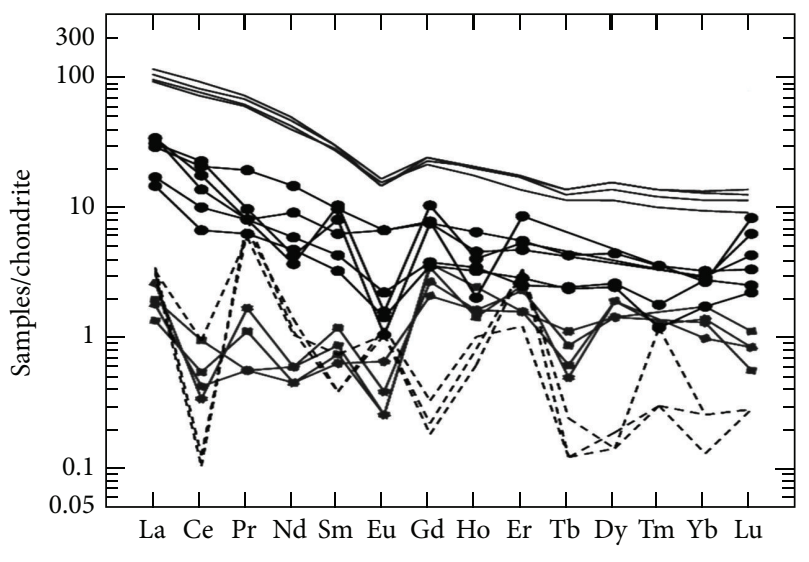

- Chah Anjir intrusive rocks

- Layered magnetite ores

$\longrightarrow$ Massive magnetite ores

- . - Hematite ores

(d)

Figure 9: (a) Distribution of the Chah Anjir samples on A-B diagram $(\mathrm{A}=\mathrm{Al}-(\mathrm{K}+\mathrm{Na}+2 \mathrm{Ca})$ and $\mathrm{B}=\mathrm{Fe}+\mathrm{Mg}+\mathrm{Ti})[31]$, (b) separation of I-type and A-type magma series according to $\mathrm{Zn}$ - $\mathrm{SiO}_{2}$ Diagrams [32], (c) $\mathrm{SiO}_{2}-\mathrm{Fe}_{2} \mathrm{O}_{3} / \mathrm{FeO}$ variation diagram showing fields for magnetite series and ilmenite series granites and intrusive rocks associated with hydrothermal iron deposits [33], (d) Chondrite-normalized REE distribution pattern of the Qatruyeh samples (Chah Anjir intrusive rocks, layered magnetite ores, massive magnetite ores, and hematite ores). Abbreviations: peraluminous ( $\mathrm{I}=$ muscovite or muscovite $>$ biotite, $\mathrm{II}=$ biotite $>$ muscovite, and $\mathrm{III}=$ biotite $)$ and metaluminous (IV = mainly hornblende and biotite + orthopyroxene + clinopyroxene + epidote + titanite, $\mathrm{V}=$ clinopyroxene \pm epidote \pm titanite, and VI $=$ exceptional igneous rocks (e.g., carbonatite).

Type A inclusions are dominated by more than 80 vol.\% of $\mathrm{H}_{2} \mathrm{O}$ at room temperature. These inclusions occur in a variety of forms: in growth zones, small clusters, and as dispersed arrays. Measurements on trapped phases were not attempted. The first ice temperature of melting $\left(T_{e}\right)$ often occurs around -24.5 to $-19.5^{\circ} \mathrm{C}$, corresponding to stable eutectic melting in the $\mathrm{NaCl}-\mathrm{MgCl}_{2}-\mathrm{CaCl}_{2}-\mathrm{H}_{2} \mathrm{O}$ system (Figure $14(\mathrm{a})$ ). Salinities determined by last ice temperature of melting $\left(T_{m}\right)$ were 3.5 to $15 \mathrm{wt} . \% \mathrm{NaCl}$ equivalent (size of inclusions between 10 and $30 \mu \mathrm{m}$ ) for inclusions trapped in whole quartz samples (Figure 14(b)). The homogenization temperature $\left(T_{h}\right)$ values change between 280 and $385^{\circ} \mathrm{C}$ (Figure 14(c)) and $\mathrm{Tm}$ measurements range from -11.3 to $-3.5^{\circ} \mathrm{C}$ (Figure $14(\mathrm{~d})$ ).
Homogenization temperature existing for primary types (A) of fluid inclusion may indicate episodes of hydrothermal activities in mesothermal systems for Fe deposits in this region.

Type B inclusions, characterized by much more gas bubble within an aqueous liquid, are commonly found in all selected samples. The inclusions are dominated by more than 45 vol. $\% \mathrm{H}_{2} \mathrm{O}-\mathrm{CO}_{2}$ at room temperature. Carbonic liquid is a visible phase as immiscible solution within $\mathrm{H}_{2} \mathrm{O}$ liquid. But, vapor bubbles of the inclusions do not contain enough $\mathrm{CO}_{2}$ to form clathrate or a visible phase of liquid $\mathrm{CO}_{2}$ during cooling. This suggests that the $\mathrm{CO}_{2}$ content of the bubble is less than 0.85 mol.\% [60]. $T_{e}$ of type B fluid inclusions (Figure 14(a)) 
| U जi in

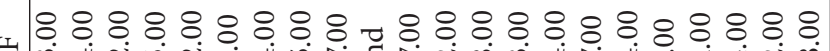
लं

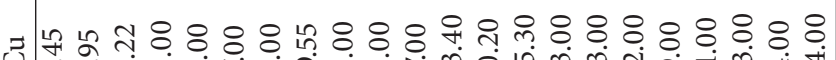
उ के

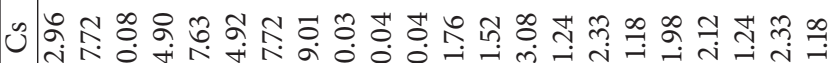
Uै

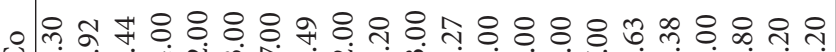
u的 ๓

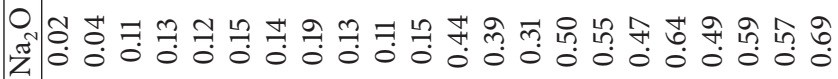

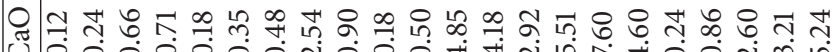

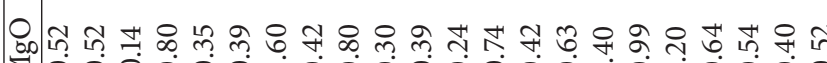

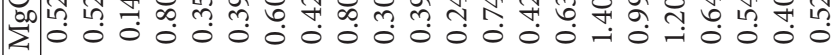

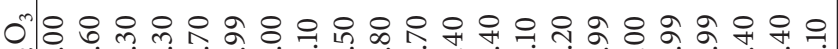

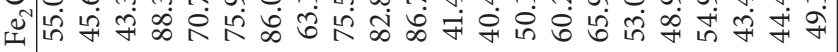

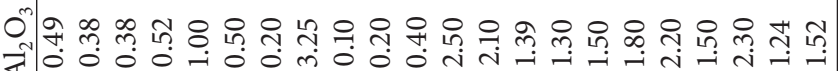

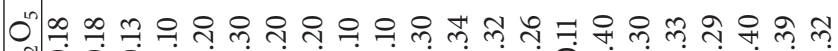

ऊँ

엄

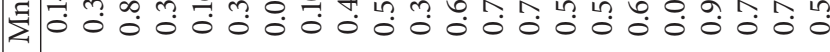

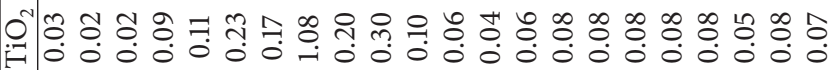

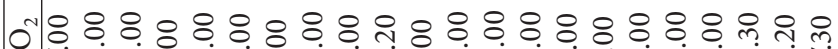

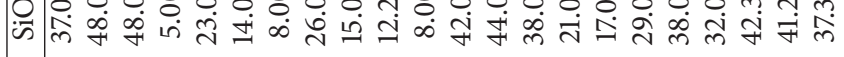

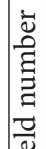

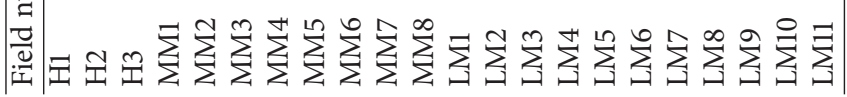

\#

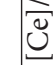

تᄑ

需

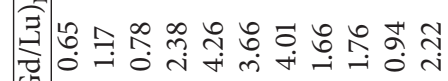

氖

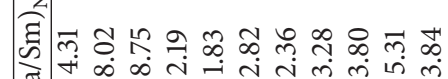

窇

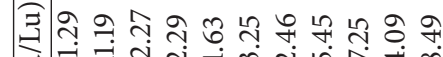
可

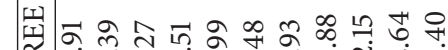

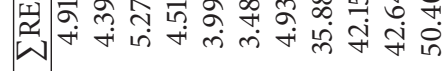

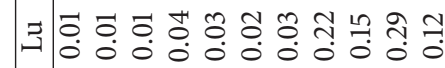

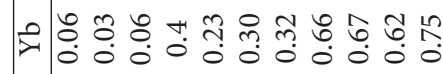

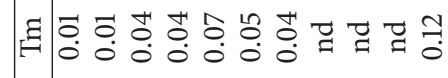
ê

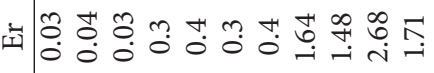

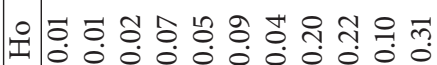

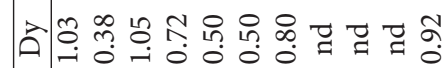

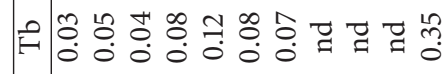

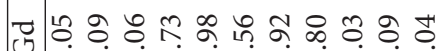

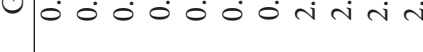

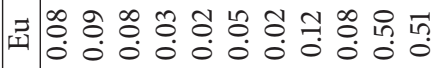

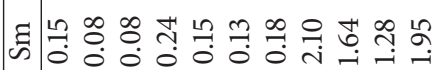

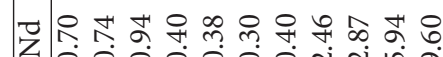

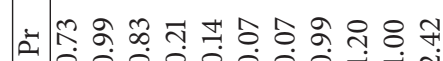

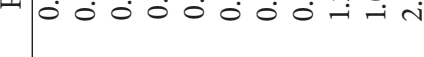

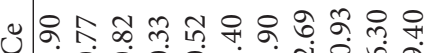

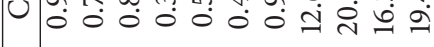

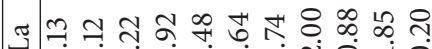

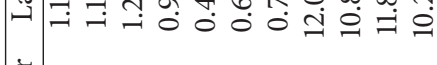
它 


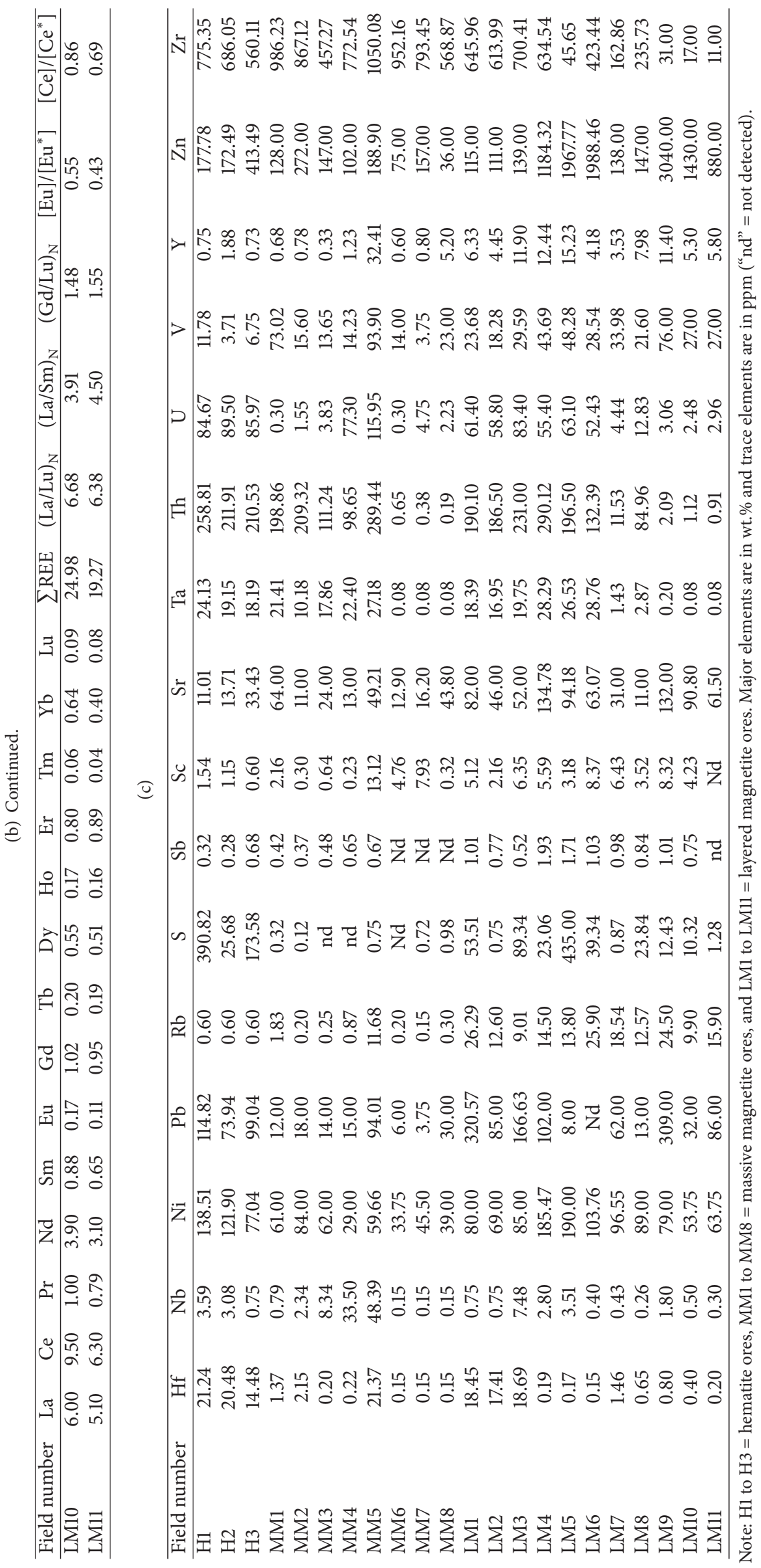




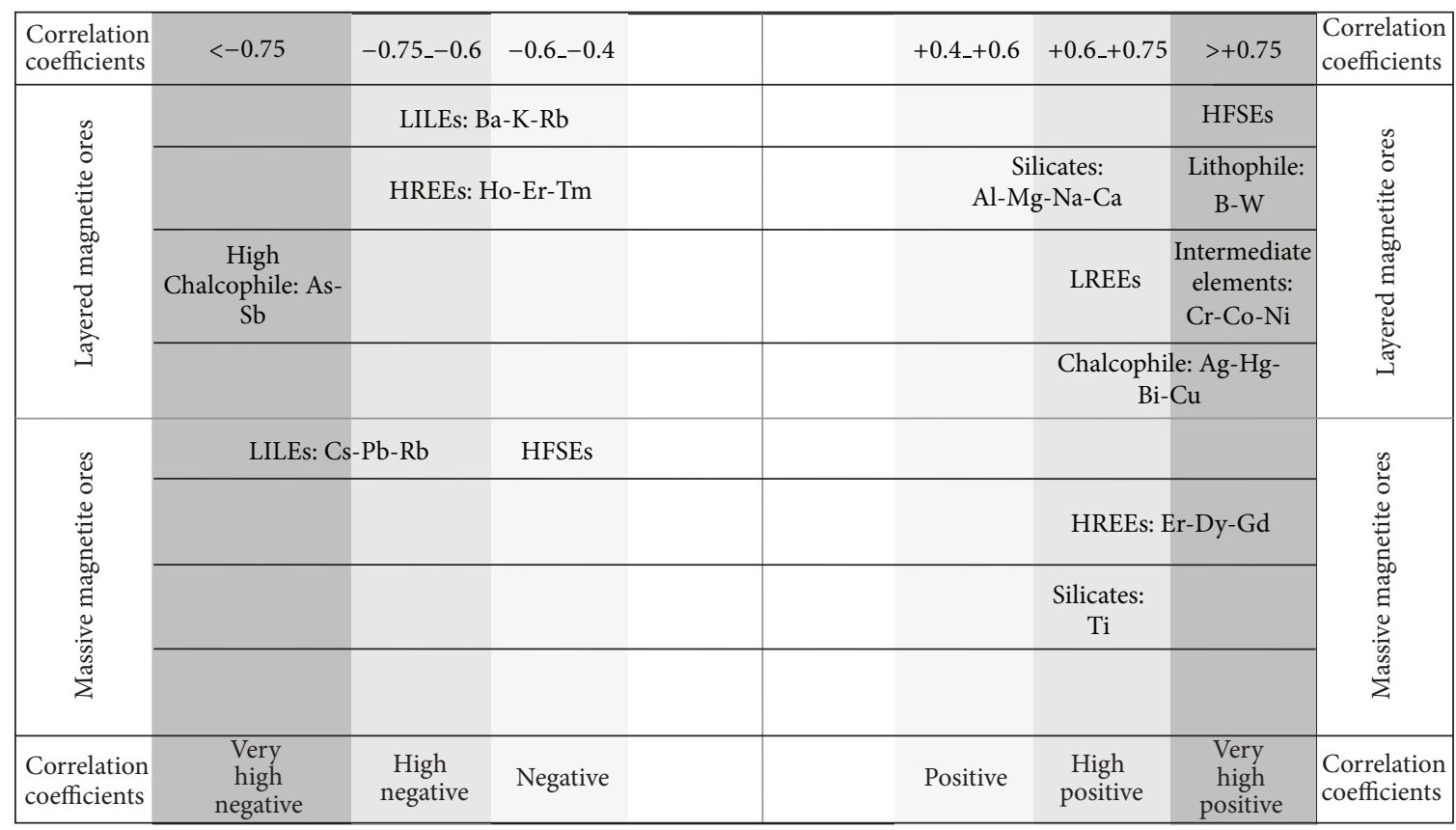

FIGURE 10: Major and trace element correlation coefficient for massive and layered magnetite ores.

is in the range of -39.5 to $-37.6^{\circ} \mathrm{C}$. The first ice melting temperatures indicate that the mineralizing fluid contained a complex mixture of metal chlorides, particularly $\mathrm{NaCl}-$ $\mathrm{MgCl}_{2}-\mathrm{CaCl}_{2}-\mathrm{FeCl}_{2}$. In this type, liquid- $\mathrm{CO}_{2}$ homogenizes to vapor in the temperature range 396 to $410^{\circ} \mathrm{C}$ (Figure $14(\mathrm{c})$ ). A general increase in $T_{h}$ values is observed for type $\mathrm{B}$ inclusions in comparison to type A. Values of $T_{m}$ of type B inclusions fall within a narrow range from -2.4 to $-1.8^{\circ} \mathrm{C}$ (Figure $14(\mathrm{~d})$ ) corresponding to low salinity, between 3.9 and 2.9 wt. $\% \mathrm{NaCl}$ equivalent. These fluids consist of mixtures of $\mathrm{H}_{2} \mathrm{O}$ and $\mathrm{CO}_{2}$, the most common fluids released during metamorphic reactions [61].

\section{Discussion}

These deposits have a number of distinct features $[15,18-$ 20, 62]: (1) an epigenetic origin, formed at moderate to high temperatures $\left(200^{\circ}-350^{\circ} \mathrm{C}\right),(2)$ volcanic, sedimentary, and metamorphosed host rocks, (3) widespread alkali-rich alteration halos, (4) the presence of hydrothermal-metasomatic magnetite and/or hematite ores, (5) a common association with calc-alkaline, I-type granitoid, (6) the presence of deep seated hydrothermal replacement and shallower brecciated textures, and (7) hydrothermal fluids with low to high salinity and $\mathrm{CO}_{2}$ and other gaseous components and also chloride complexes for iron mobilization. This indicates that no single genetic model can be developed for hydrothermal Fe-oxide deposits [17, 18, 22-25, 63, 64].

There are some similarities between the Qatruyeh iron ores and hydrothermal Fe-oxide deposits such as Andean iron oxide and Iron springs Utah deposits [15, 18]; these are (1) occurrence of ore bodies along a subduction-related active continental margin, (2) abundances of magnetite with lesser hematite, (3) the presence of breccia and replacement textures, (4) iron oxides with low Ti contents, (5) uranium anomalies, and (6) chemical analyses results of magmatic rock samples of the Qatruyeh similar to those of calc-alkaline plutonic rocks in Andean iron belt (Table 1). At the Qatruyeh area, titanium in both types of magnetite ores was depleted like to other hydrothermal iron deposits. It was concentrated in early magmatic ferromagnesian minerals in mafic rocks and hence was depleted in the residual late magmatic hydrothermal fluids. Layered magnetite and hematite ores related to massive magnetite in the Qatruyeh area generally have anomalous, though uneconomic, uranium grades. The relatively high values of uranium could be related to uraniumrich magmatic fluids from causative intrusions, particularly magnetite-series intrusions such as the Chah Anjir plutonic rocks at the Qatruyeh area. Alternatively, uranium could be contributed by a second fluid mixing with hydrothermal fluids at the site of mineralization or it may have been leached from host rocks [65]. The hydrothermal systems within intermediate to mafic calc-alkaline sequences, such as the subduction-related deposits of the Andean iron belt, would be expected to have low uranium contents. Therefore, uranium-rich iron oxide systems with relatively low copper values (e.g., the Qatruyeh area) suggest the presence of iron oxide uranium deposits and may be important exploration targets [65]. On this basis, the intermediate intrusions would be considered as a potential source of mineralizing components for the iron ore deposits.

HFSEs were immobile in the metacarbonate rocks, whereas large-ion lithophile elements were mobile during hydrothermal alteration and associated iron mineralization.

According to major oxide analyses of magnetite, the high $\mathrm{Na}_{2} \mathrm{O}$ content in magnetite is called alkali iron effect [15] 
ธึฝิ

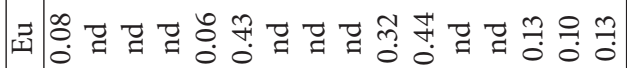

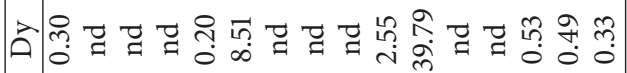

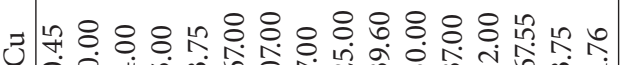

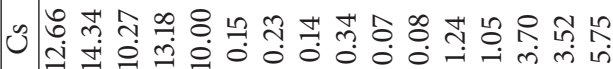

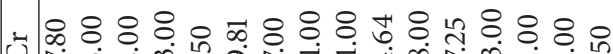
U

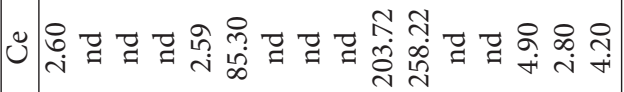

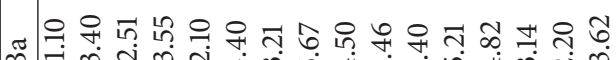
๓

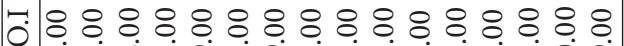

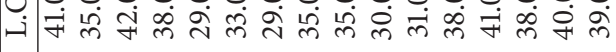

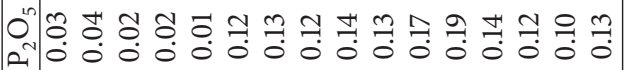

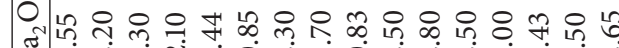

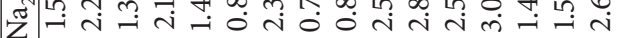

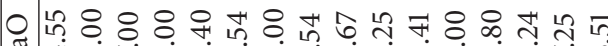
نூ

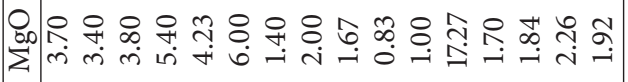

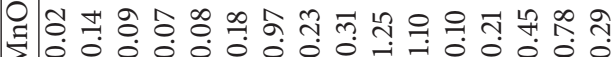

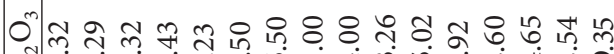

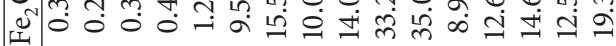

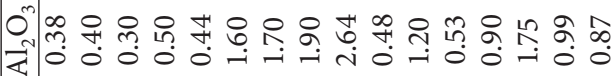

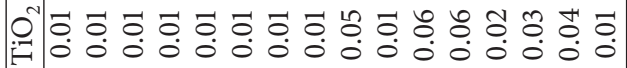
০৷:8: m.

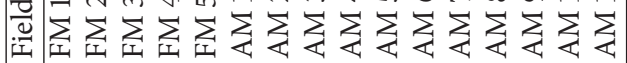

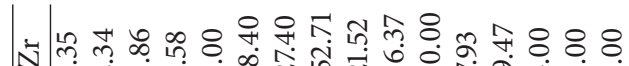
N

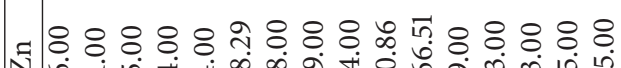
N

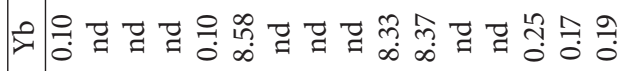

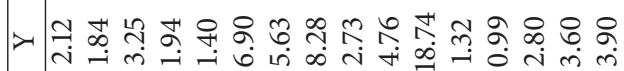

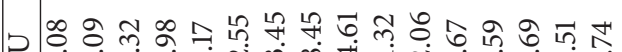

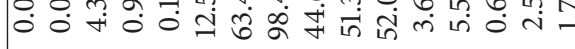

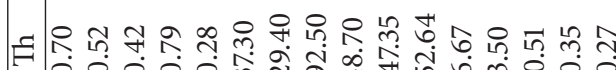

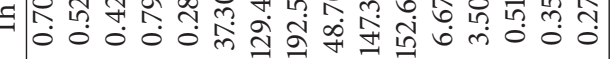

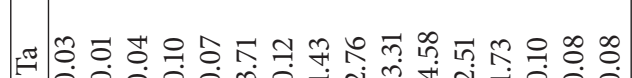
- o. 000 mí.

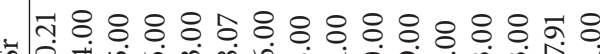

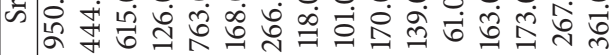

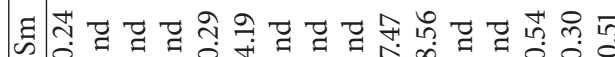
Uు $\hat{e}$

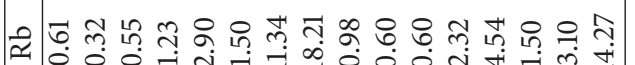

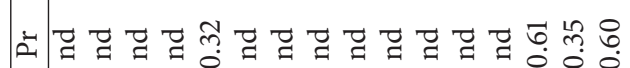

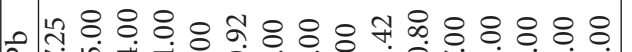
会它

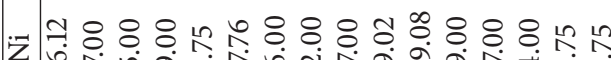
z

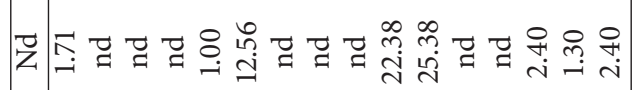

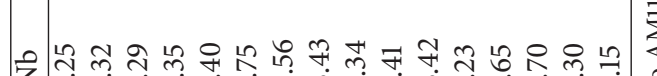

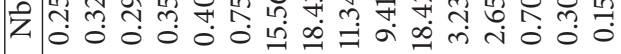

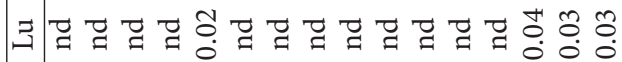

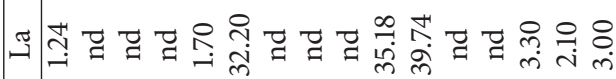

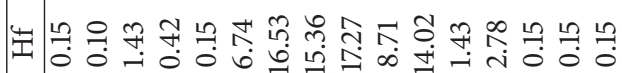




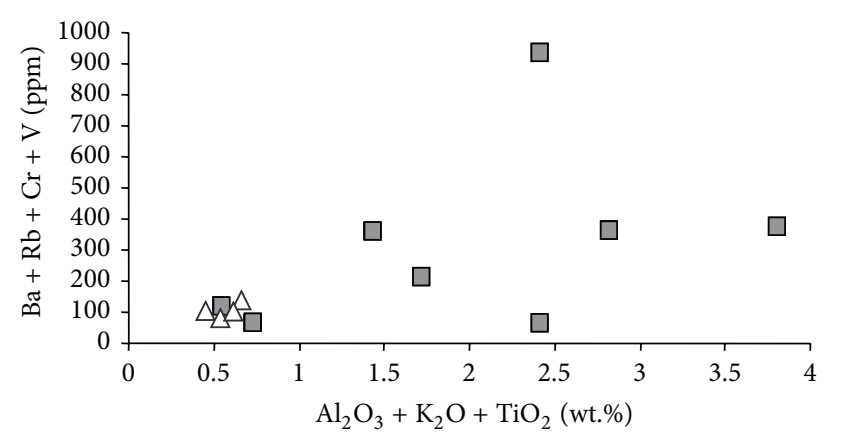

Altered

$\triangle$ Fresh

FIgURE 11: Plot of minor elements $(\mathrm{Ba}+\mathrm{Rb}+\mathrm{Cr}+\mathrm{V})$ versus major elements $\left(\mathrm{Al}_{2} \mathrm{O}_{3}+\mathrm{K}_{2} \mathrm{O}+\mathrm{TiO}_{2}\right)$ in altered and fresh dolomitic marbles at the Qatruyeh area.

and the system, such as $\mathrm{FeO}+\mathrm{Na}_{2} \mathrm{O}+\mathrm{K}_{2} \mathrm{O}+\mathrm{Al}_{2} \mathrm{O}_{3}+$ $\mathrm{MgO}$ and $\mathrm{FeO}+\mathrm{MnO}+\mathrm{TiO}_{2}+\mathrm{CaO}+\mathrm{P}_{2} \mathrm{O}_{5}+\mathrm{SiO}_{2}$, kept iron in solution at temperatures significantly lower than the melting point of magnetite at rather shallow depth [66]. The role of other volatile constituents such as $\mathrm{CO}_{2}$ and $\mathrm{F}$ is also important in this process [67]. The $\mathrm{PCO}_{2}$ at the Qatruyeh may have been raised by the assimilation of dolomitic-marble host rock by iron-rich hydrothermal fluids, as is evidenced by the presence of carbonate xenoliths in the magnetite ore.

The REE distribution in hydrothermal minerals is often used for discussing ore genesis. It is influenced by chemicalcrystallographical constraints, kinetics of crystallization, $P-T$ conditions, and the composition of the hydrothermal fluids [68]. In addition, it is necessary to take into account the effect of subsequent metamorphism and hydrothermal alteration when using REE data in ore genetic discussions. REEs geochemical investigations on the metacarbonate host rocks were shown that these elements were moderately mobilized due to metasomatic-alteration in the study area. Alderton et al. [69] stated that REE mobilization in fluids is controlled largely by (1) the REE concentrations of the reacting minerals; (2) the relative stability of these minerals against the fluid; (3) the availability of suitable crystallographic sites within the secondary minerals to accommodate released REE during alteration; (4) the REE concentrations of the hydrothermal fluid; and (5) the ability of the fluid phase to remove REE from the system.

Besides, the REE patterns for magnetite, as well as their geochemical character, show a clear difference between the high-grade and low-grade ores. The similarity of REE patterns in the layered magnetite ores and magmatic rocks is consistent with this conclusion that the layered magnetite was formed from magmatic derived hydrothermal fluids. On the contrary, different REE distribution patterns in massive magnetite indicate that these ores formed by dissimilar agents and processes at different times (e.g., by metamorphic fluids derived from dehydration and decarbonation reactions during prograde metamorphism). The metamorphic grade of the Qatruyeh area has been determined to epidote-amphibolite facies, which according to Apted and Liou [70] took place between 575 and $675^{\circ} \mathrm{C}$ (at $7 \mathrm{~kb}$ ) and could consequently have produced hot fluids enough for magnetite mineralization. Also, Magnetite is not normally a major REE-bearing mineral; due to the small ionic radius of Fe therefore it has a very little influence on the REE budget in the hydrous systems. In contrast, the silicate partition coefficients for the REE are highest in such systems [71]. LREEs enrichment in low-grade ores is opposite to what one should expect based on the small ionic radius of the iron site. Schock [72] cited analyses of magnetite contained $\mathrm{Ca}^{2+}$ ions in its structure. He further noted the plausibility that REE ions with comparable ionic radii to $\mathrm{Ca}^{2+}$ (7- and 9-fold coordination with ionic radii of 1.06 and $1.18 \AA$, resp.) could also enter the same lattice sites. Frietsch and Predhal [73] according to de Sitter et al. [74] have showed substitution of $\mathrm{Ca}^{2+}$ ions for ferrous ion in the magnetite structure, which can contain up to $6.67 \mathrm{wt} . \% \mathrm{Ca}^{2+}$, corresponding to the composition $\left(\mathrm{Fe}_{2.8} \mathrm{Ca}_{0.2}\right) \mathrm{O}_{4}$. The large ionic radius of $\mathrm{Eu}^{2+}$ (7- and 9-fold coordination with ionic radii of 1.20 and $1.30 \AA$, resp.) discriminates against, is in contradiction to incorporation into the magnetite. Accordingly, the negative $\mathrm{Eu}$ anomaly in low-grade magnetite indicates $\mathrm{Eu}$ enrichment in the remaining hydrothermal fluids after iron ore formation. Divalent Eu will thus be stable over a wide range of $\mathrm{pH}$ values at the magnetite-hematite buffer and moderate to high temperature hydrothermal systems, due to its large ionic radius. But, trivalent $\mathrm{Eu}$ will become the stable species when the system cools or becomes extremely oxidized [75]. The positive Eu anomalies in the Qatruyeh hematite ores reflect cooling of the Eu-enriched hydrothermal fluid subsequent to iron ore deposition.

The difference in $\mathrm{Cl}$ contents among layered magnetite, massive magnetite, and hematite can be explained by metalligand complexation. Zhu and Sverjensky [76] demonstrated that partitioning of $\mathrm{F}$ and $\mathrm{Cl}$ between minerals and hydrothermal fluids is a strong function of temperature, pressure, $\mathrm{pH}$, and fluid composition. Chloride solutions are very adequate to transport enough metals to form deposits [77]. According to these authors, the $\mathrm{Cl} / \mathrm{F}$ ratio increases with increasing temperature and pressure. The $\mathrm{Cl}^{-}$ion is a high intermediate Lewis acid ligand and will affect the solubility of divalent metals (e.g., $\mathrm{Fe}^{2+}$ ) in hydrothermal solutions, forming a range of iron minerals such as sulfides (pyrite and chalcopyrite) and carbonates (siderite) [78-80], as observed in the Qatrureh area. Most experimental studies indicate that $\mathrm{FeCl}^{+}$and $\mathrm{FeCl}_{2}$ are the main complexes involved in the hydrothermal transport of ferrous iron, especially at high temperatures $\left(>300^{\circ} \mathrm{C}\right)$. At the Qatruyeh, $\mathrm{Cl}$ concentration in the hematite ores relative to layered magnetite decreases with respect to increasing $\mathrm{pH}$ and decreasing temperature due to interaction between dolomitic marbles and primitive acidichigh temperature hydrothermal fluids. Therefore, a higher $\mathrm{pH}$ of the fluids should indicate higher concentrations of $\mathrm{Cl}$ in the layered magnetite relative to hematite. High $\mathrm{Cl}$ value records related to $\mathrm{Fe}$ in the Qatruyeh iron ores are good evidences for mentioned complexes in Cl-F-Fe triangular diagram (Figure 15(a)). From these data, it is clear that lower $\mathrm{pH}$, higher concentrations of chloride complex as a ligand, 


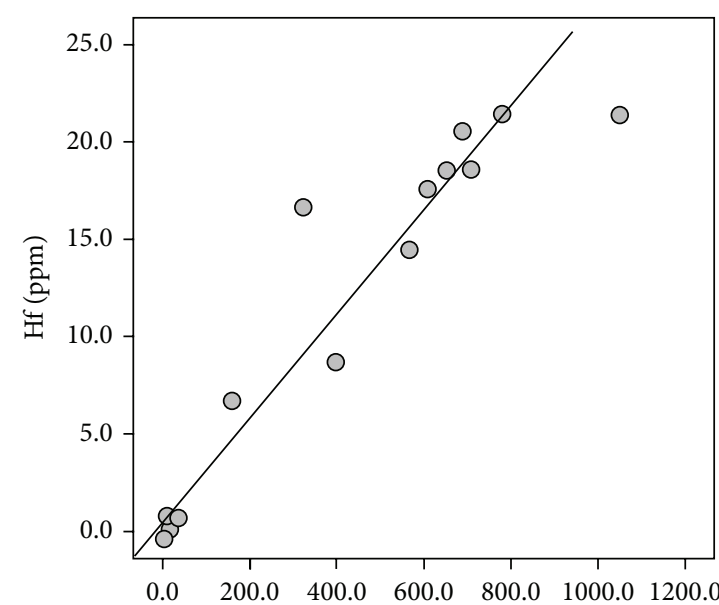

(a)

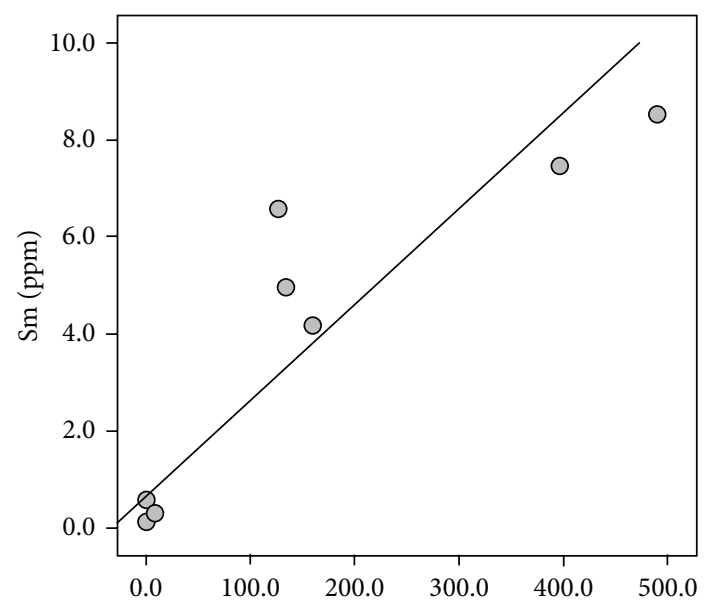

(c)

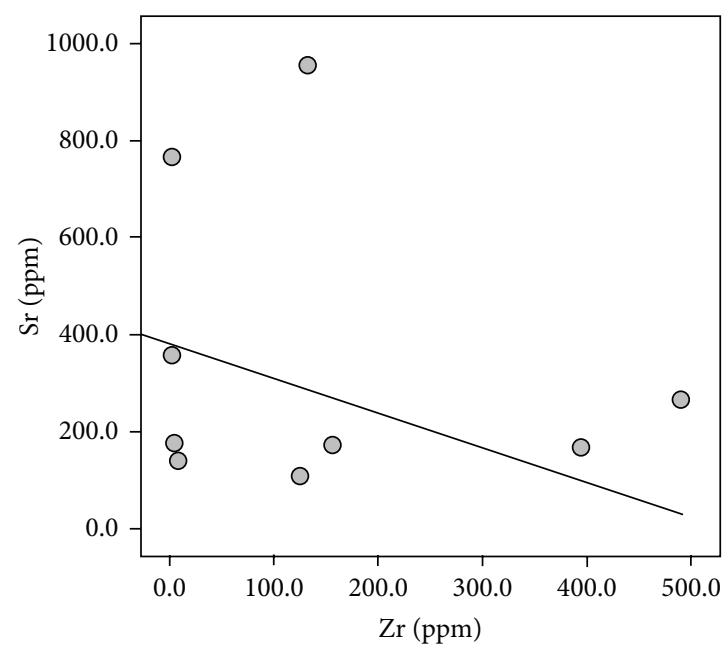

(e)

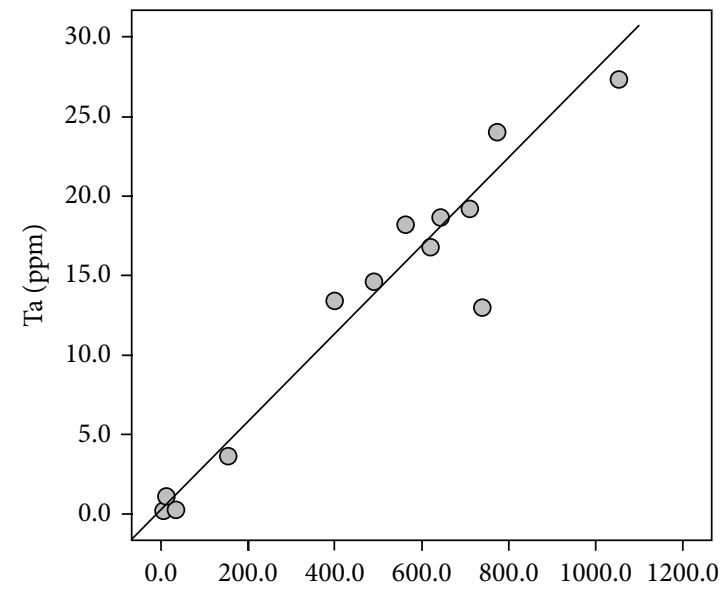

(b)

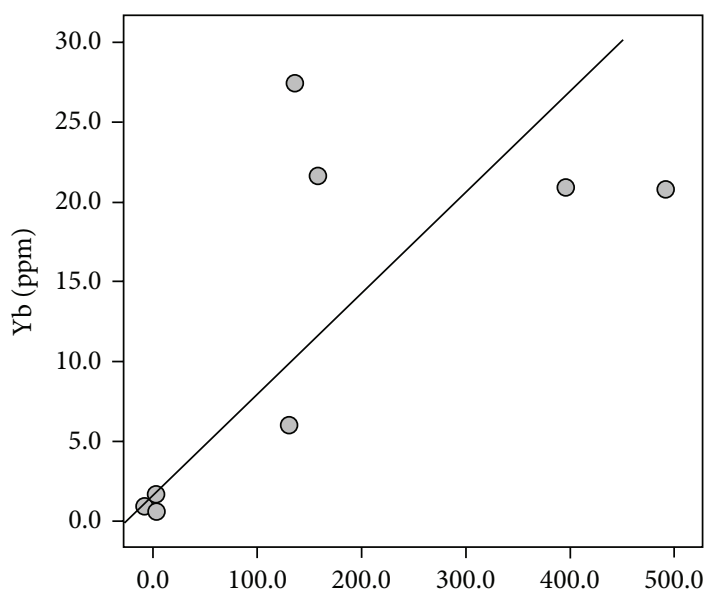

(d)

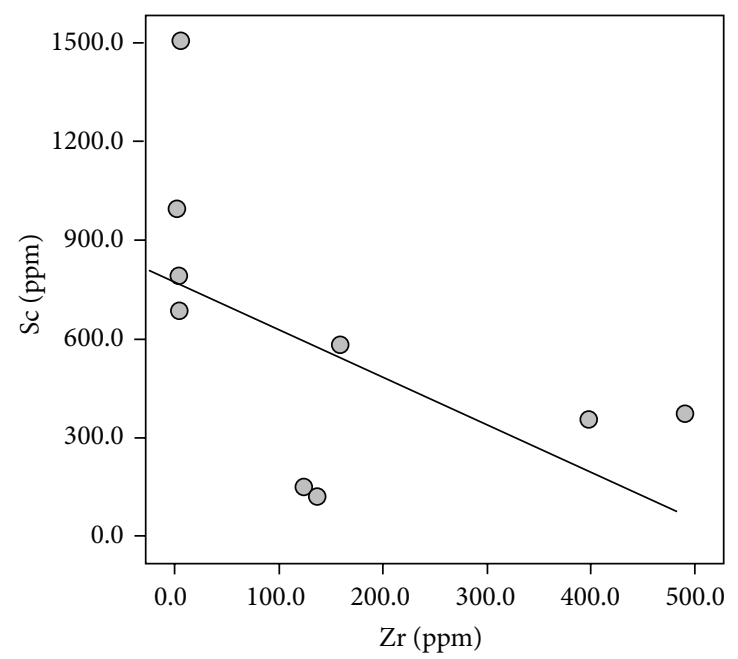

(f)

Figure 12: Binary trace element plots for dolomitic-marble samples of the Qatruyeh area. (a) and (b) high field strength elements (Ta and Hf), (c) and (d) rare earth elements (Yb and Sm), and (e) and (f) large ion lithophile elements (Sr and Sc). 

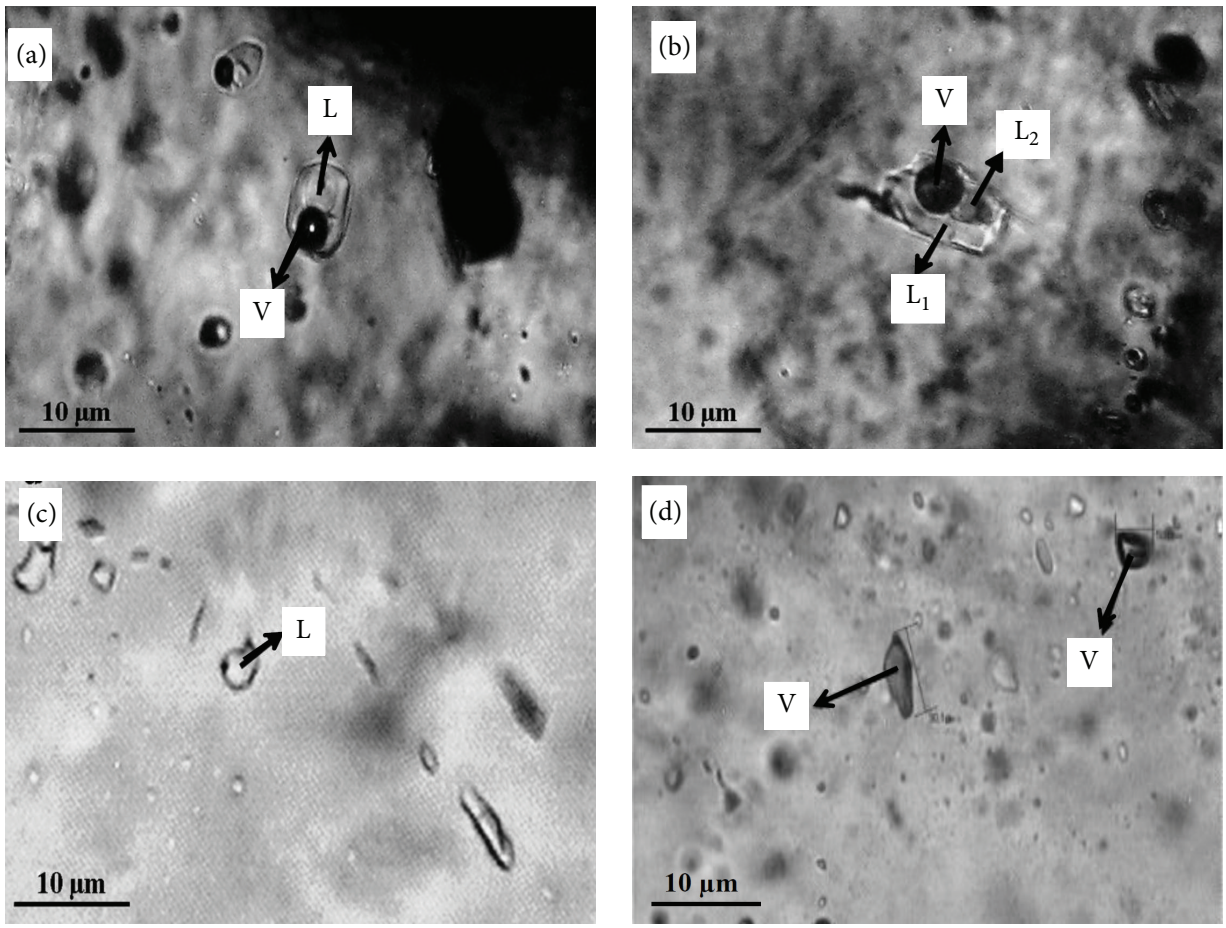

Figure 13: Photomicrographs of different fluid inclusions in quartz from layered magnetite at the Qatruyeh (crossed nicols). (a) Fluid inclusions with two-phase liquid + vapor (type A), (b) fluid inclusions with three-phase vapor + liquid $\left(\mathrm{L}_{1}\right)+\mathrm{CO}_{2}$ liquid $\left(\mathrm{L}_{2}\right)($ type $\mathrm{B})$, (c) fluid inclusions with monophase liquid (type C), and (d) fluid inclusions with monophase vapor (type D).

or higher temperatures usually increase the capability of hydrothermal fluids to carry sufficient Fe and REE to explain the observed $\sum$ REE-enrichments in all layered magnetite relative to massive magnetite and hematite ores in Cl-F$\sum$ REE trigonal diagram (Figure 15(b)).

Field observations and microscopic studies indicate two different alternative genetic concepts for ore mineralization in the Qatruyeh area. A syn-metamorphic or premetamorphic origin for the massive magnetite is supported by our observations on pebbles of the Jurassic Deh Vazir conglomerate. Magnetite recrystallization and the presence of ductile deformation textures are clear evidence for origin of layered magnetite and hematite ores later to peak of Cimmerian metamorphism followed the continental collision events.

Fluid inclusion study has proven to be an important tool for constraining the physicochemical conditions of hydrothermal mineralization [81]. The microthermometric results and the moderate salinity of the studied fluid inclusions suggest that mineralization at the Qatruyeh occurred under mesothermal conditions. At the Qatruyeh area similar to other mesothermal deposits, ore forming system is accompanied by both replacement and brecciated textures with the latter more common in shallower deposits and well developed alteration patterns [62], with sodic-calcite alteration in depth and the propylitic-hematitization haloes in shallower depths $[11,53,62]$. Hematite and quartz ( \pm pyrite \pm chalcopyrite) veins accompanied the late stage of each main ore mineralization in the Qatruyeh area.
The fluid inclusion study data also indicate that the ore forming fluids at the Qatruyeh were $\mathrm{CO}_{2}$-bearing, low to moderately saline, $\mathrm{NaCl}-\mathrm{MgCl}_{2}-\mathrm{CaCl}_{2}-\mathrm{H}_{2} \mathrm{O}$ rich fluids. The source of the fluids (magmatic or metamorphic origin) could not be unequivocally determined from the available data; nevertheless, the distribution of fluid inclusions in $\left(T_{h}\right)$ salinity diagram [34], with lines of constant fluid density imply cooling and increasing of $\mathrm{pH}$, boiling, and fluid mixing, may play an important role in the iron ore deposition in the area (Figure 16). Cooling and increasing of $\mathrm{pH}$ are the main factors affecting precipitation of layered magnetite minerals. However, other processes such as fluid mixing and boiling also seem to be effective on such a precipitation. The precipitation of layered magnetite ores and actinolite was occurred by cooling and an increasing of $\mathrm{pH}$ due to reaction of ore bearing fluids with dolomitic-marble rocks. For example, in a simplified reaction:

$$
\begin{aligned}
5 \mathrm{CaMg} & \left(\mathrm{CO}_{3}\right)_{2}+8 \mathrm{SiO}_{2}+5 \mathrm{H}_{2} \mathrm{O}+8 \mathrm{FeCl}^{+} \\
\longleftrightarrow & \mathrm{Ca}_{2}(\mathrm{Mg}, \mathrm{Fe})_{5} \mathrm{Si}_{8} \mathrm{O}_{22}(\mathrm{OH})_{2} \\
& +8 \mathrm{H}^{+}+n \mathrm{Cl}^{-}+\mathrm{Fe}_{3} \mathrm{O}_{4}+3 \mathrm{CaCO}_{3}+7 \mathrm{CO}_{2} .
\end{aligned}
$$

An increase in $\mathrm{pH}$ will move the reaction to the right side, resulting in the precipitation of magnetite and actinolite [78].

Boiling results in the production of vapor and loss of $\mathrm{H}_{2} \mathrm{O}$, and other volatile species occur. Salinity variations (from 3.5 to $15 \mathrm{wt} . \% \mathrm{NaCl}$ equiv.) in the fluid inclusions 


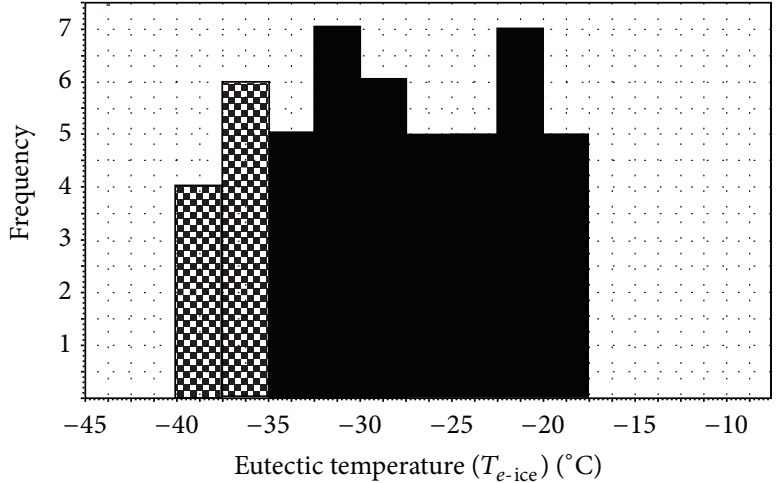

(a)

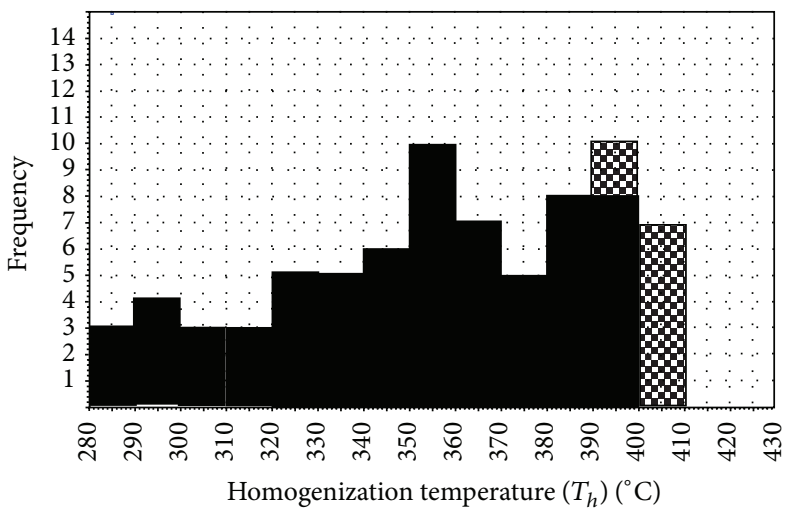

A type

B B type

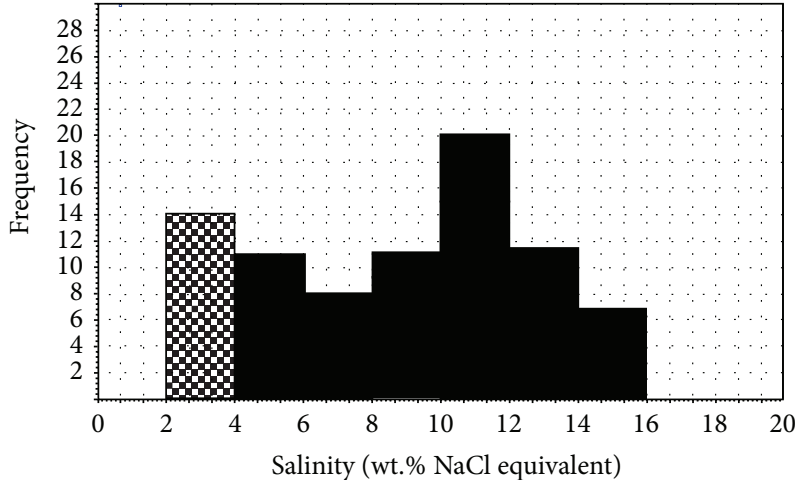

(b)

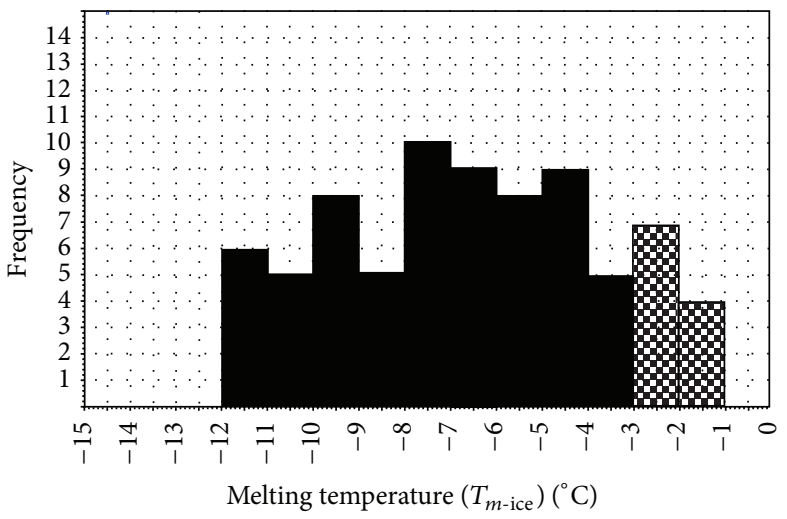

A type

B B type

(c)

(d)

FIGURE 14: Fluid inclusion data plotted in histograms. (a) Distribution of first ice-melting temperatures or eutectic temperatures $\left(T_{e}\right)$, (b) frequency distribution of salinity based on weight percent $\mathrm{NaCl}$ equivalent (wt. \% NaCl equivalent), (c) distribution of homogenization temperatures $\left(T_{h}\right)$, and (d) distribution of last ice-melting temperatures $\left(T_{m}\right)$.

data can be produced by boiling. This accompaniment to cooling would result in production of a relatively high-density liquid phase. Figure 16 shows that the density of mineralizing fluid at the Qatruyeh ranged from 0.6 to $0.93 \mathrm{~g} \mathrm{~cm}^{-3}$. In addition, some fluid inclusions that contain relatively high concentrations of $\mathrm{CO}_{2}$ in quartz can be constructed assuming a model involving a fluid rising adiabatically and mixing with metamorphic fluids.

\section{Conclusions}

Based on ore mineral types and alteration assemblages, the mineralization processes have been divided into the following stages: (I) layered magnetite ore stage, (II) sulfide ore stage, and (III) hematite ore stage. Stage I involved the formation of the layered magnetite ore, high temperature hydrothermal activity, replacement textures, and assemblages of actinolite + quartz + titanite + siderite + paragonite \pm tourmaline. Stage II partially overlapped with stage I and includes hematite ores with epidote + chlorite + sericite + quartz \pm magnetite assemblages. Propylitic zones with associated hematite ores and brecciated textures are shown by low-temperature oxidizing- hydrothermal fluids in shallow levels due to cooling and fluid mixing at this stage. Stage III involved the formation of hematite and quartz veins and some minor sulfide minerals as chalcopyrite and pyrite. Therefore, the evolution of hydrothermal fluids varies due to fluiddolomitic-marble interaction from acidic to alkaline affinity during iron mineralization.

The low-grade magnetite ores and diorites whole rock REE patterns are comparable to each other, indicating that the bulk of REE concentration in low-grade magnetite is inherited from precursor diorite during the replacement process that was obvious in ore textures. Besides, trace elements geochemical investigation of the metamorphosed carbonate host rocks shows that

(1) HFSEs, such as Th, Hf, Zr, and Ta, were immobile during hydrothermal alteration and iron mineralization.

(2) REEs were moderately mobile, whereas large ion lithophile elements such as $\mathrm{Ba}, \mathrm{Sr}, \mathrm{Rb}$, and $\mathrm{Cs}$ were depleted during the alteration and iron mineralization. 


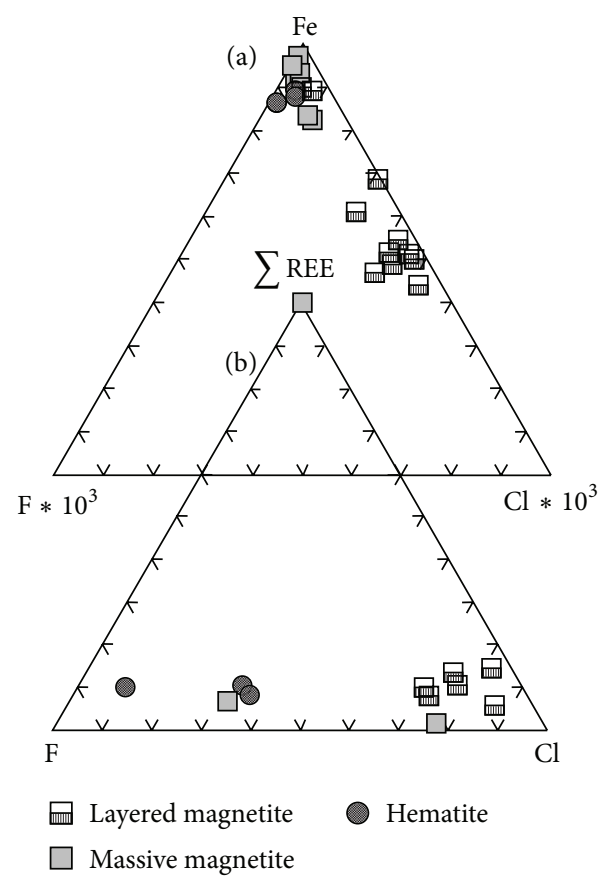

FIGURE 15: Triangular plots for determination of ligand-metal complexes in iron ores at the Qatruyeh area. (a) Fe-Cl-F triangular plots and (b) $\sum$ REE-Cl-F triangular plots.

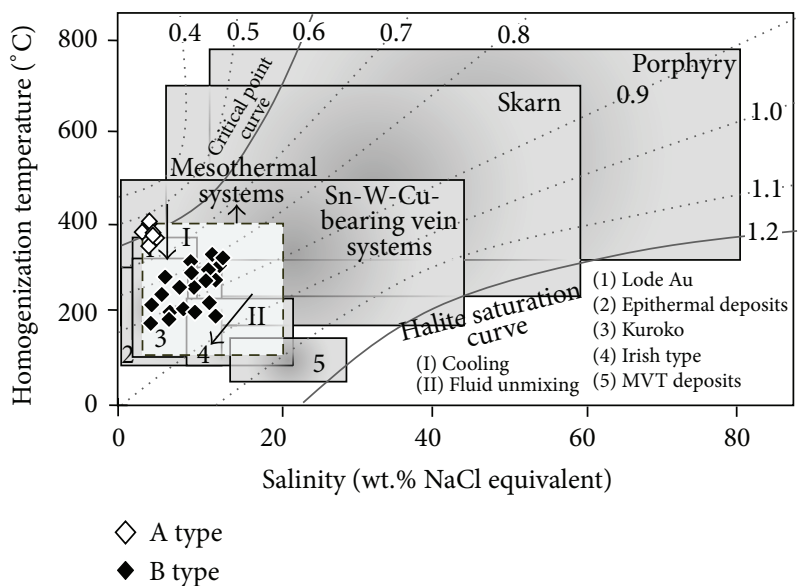

FIGURE 16: The most important factors for iron precipitation at Qatruyeh area in homogenization temperature $\left(T_{h}\right)$-salinity diagram [34].

From the available data, it is not obvious whether the massive magnetite formed from an iron-rich melt or through metasomatism but the presence of magnetite pebbles in the Jurassic Deh Vazir conglomerate indicates that a part of ore mineralization occurred syngenetic or premetamorphic.

Fluid inclusion data suggest that low to moderate saline fluid (3.5 to $15 \mathrm{wt} \% \mathrm{NaCl}$ equiv.) was possibly responsible for the development of low-grade magnetite ore that indicates episodes of hydrothermal activities in mesothermal systems for $\mathrm{Fe}$ occurrences in this region. The microthermometric data reflect variable amounts of magmatic fluids and low salinity metamorphic fluids. The temperature during the main mineralization event was between $300^{\circ}$ and $410^{\circ} \mathrm{C}$. Increase in $\mathrm{pH}$ due to reaction of ore fluids with dolomitic-marble rocks and effervescence can be effective mechanisms of ore precipitation. In addition, mixing with cooler probably metamorphic fluids had the effect of decreasing the salinity and temperature of the equilibrated magmatic fluid, making it more buoyant and capable of moving out from the apophyses into the host rocks, causing metasomatic reactions and precipitating low-grade magnetite ores from chloride-bearing hydrothermal fluids.

\section{Conflict of Interests}

The authors declare that there is no conflict of interests regarding the publishing of this paper. 


\section{Acknowledgments}

The authors would like to thank the research council of Shiraz University for financing this research (Grant no. 88GR-SC-83). They express gratitude to professor Nigel. J. Cook (University of Adelaide) who provided many insightful and constructive comments that greatly improved the paper. They would like also to thank professor Warren. C. Day (US Geological Survey) for criticism of an early version of the paper.

\section{References}

[1] A. A. Bookstrom, "The magnetite deposits of El Romeral, Chile," Economic Geology, vol. 72, no. 6, pp. 1101-1130, 1977.

[2] A. R. Philpotts, "Origin of certain iron-titanium oxide and apatite rocks," Economic Geology, vol. 62, no. 3, pp. 303-315, 1967.

[3] A. R. McBirney and H. R. Naslund, "The differentiation of the Skaergaard Intrusion-a discussion of Hunter and Sparks," Contributions to Mineralogy and Petrology, vol. 104, no. 2, pp. 235-240, 1990.

[4] J. O. Nystrom and F. Henriquez, "Magmatic features of iron ores of the Kiruna type in Chile and Sweden: ore textures and magnetite geochemistry," Economic Geology, vol. 89, no. 4, pp. 820-839, 1994.

[5] F. Henríquez and J. O. Nyström, "Magnetite bombs at El Laco volcano, Chile," GFF, vol. 120, no. 3, pp. 269-271, 1998.

[6] H. R. Naslund, R. Aguirre, F. M. Dobbs et al., "The origin, emplacement and eruption of ore magmas," IX Congreso Geologico Chileno, vol. 2, pp. 135-139, 2000.

[7] F. Henriquez, R. Naslund, J. O. Nystrom et al., "New field evidence bearing on the origin of the el laco magnetite deposit, Northern Chile-a discussion," Economic Geology, vol. 98, no. 7, pp. 1497-1500, 2003.

[8] R. S. Hildebrand, "Kiruna-type deposits: their origin and relationship to intermediate subvolcanic plutons in the Great Bear magmatic zone, northwest Canada," Economic Geology, vol. 81, no. 3, pp. 640-659, 1986.

[9] N. Oreskes and M. T. Einaudi, "Origin of rare earth elementenriched hematite breccias at the Olympic Dam Cu-U-Au-Ag deposit, Roxby Downs, South Australia," Economic Geology, vol. 85, no. 1, pp. 1-28, 1990.

[10] E. C. T. Chao, J. M. Back, J. A. Minkin, and R. Yinchen, "Hostrock controlled epigenetic, hydrothermal metasomatic origin of the Bayan Obo REEFe-Nb ore deposit, Inner Mongolia, P.R.C.," Applied Geochemistry, vol. 7, no. 5, pp. 443-458, 1992.

[11] M. W. Hitzman, N. Oreskes, and M. T. Einaudi, "Geological characteristics and tectonic setting of proterozoic iron oxide (CuUAuREE) deposits," Precambrian Research, vol. 58, no. 1-4, pp. 241-287, 1992.

[12] A. A. Bookstrom, "Magmatic features of iron ores of the kiruna type in Chile and Sweden: ore textures and magnetite geochemistry-a discussion," Economic Geology, vol. 90, no. 2, pp. 469-473, 1995.

[13] A. L. Rhodes, N. Oreskes, and S. Sheets, "Geology and rare earth element geochemistry of magnetite deposits at El Laco, Chile," in Geology and ore deposits of the Central Andes. Special Publication 7, B. J. Skinner, Ed., pp. 299-332, Society of Economic Geologist, Littleton, Colo, USA, 1999.
[14] R. H. Sillitoe and D. R. Burrows, "New field evidence bearing on the origin of the El Laco magnetite deposit, Northern Chile," Economic Geology, vol. 97, no. 5, pp. 1101-1109, 2002.

[15] J. M. Guilbert and C. F. Park, The Geology of Ore Deposits, W.H. Freeman, New York, NY, USA, 1997.

[16] J. A. Hunt, T. Baker, and D. J. Thorkelson, "A review of iron oxide copper-gold deposits, with focus on the Wernecke Breccias, Yukon Canada, as an example of a non-magmatic end member and implications for IOCG genesis and classification," Exploration and Mining Geology, vol. 16, no. 3-4, pp. 209-232, 2007.

[17] T. M. Porter, Hydrothermal Iron Oxide Copper-Gold and Related Deposits: A Global Perspective, PGC Publishing, Adelaide, Australia, 2nd edition, 2002.

[18] R. H. Sillitoe, "Iron oxide-copper-gold deposits: an Andean view," Mineralium Deposita, vol. 38, no. 7, pp. 787-812, 2003.

[19] M. W. Hitzman, "Iron oxide-Cu-Au deposits, what, where, when and why," in Hydrothermal Iran Oxide Copper-Gold and Related Deposits: A Global Perspective, Australian Mineral Foundation, T. M. Porter, Ed., vol. 1, pp. 9-25, Australian Mineral Foundation, Adelaide, Australia, 2000.

[20] R. G. Skirrow and J. L. Walshe, "Reduced and oxidized Au-CuBi iron oxide deposits of the Tennant Creek Inlier, Australia: an integrated geologic and chemical model," Economic Geology, vol. 97, no. 6, pp. 1167-1202, 2002.

[21] S. A. Eshraghi, J. Roshan Ravan, and M. Sabzehei, "Geological map of the Quatruyeh area, scale 1:100,000," Geological Survey of Iran, 1999.

[22] M. D. Barton and D. A. Johnson, "Evaporitic-source model for igneous-related Fe oxide-(REE-Cu-Au-U) mineralization," Geology, vol. 24, pp. 259-262, 1996.

[23] M. D. Barton and D. A. Johnson, "Alternative brine sources for Fe-Oxide (-Cu-Au) systems: implications for hydrothermal alteration and metals," in Hydrothermal Iron Oxide Copper-Gold \& Related Deposits: A Global Perspective, T. M. Porter, Ed., vol. 1, pp. 43-60, Australian Mineral Foundation, 2000.

[24] M. D. Barton and D. A. Johnson, Footprints of Fe Oxide (-CuAu) Systems, vol. 33 of Special Publication, University of Western Australia, Crawley, Australia, 2004.

[25] A. Mücke and R. Younessi, "Magnetite-apatite deposits (Kiruna-type) along the Sanandaj-Sirjan zone and in the Bafq area, Iran, associated with ultramafic and calcalkaline rocks and carbonatites," Mineralogy and Petrology, vol. 50, no. 4, pp. 219-244, 1994

[26] H. De la Roche, J. Leterrier, P. Grandclaude, and M. Marchal, "A classification of volcanic and plutonic rocks using R1R2diagram and major-element analyses-its relationships with current nomenclature," Chemical Geology, vol. 29, no. 1-4, pp. 183-210, 1980.

[27] K. G. Cox, J. D. Bell, and R. J. Pankhurst, The Interpretation of Igneous Rocks, George Allen and Unwin, London, UK, 1979.

[28] M. Wilson, Igneous Petrogenesis; A Global Tectonic Approach, Unwin Hyman, London, UK, 1989.

[29] T. N. Irvine and W. R. A. Baragar, "A guide to chemical classification of the common volcanic rocks," Canadian Journal of Earth Sciences, vol. 8, no. 5, pp. 523-548, 1971.

[30] J. A. Pearce, N. B. W. Harris, and A. G. Tindle, "Trace element discrimination diagrams for the tectonic interpretation of granitic rocks," Journal of Petrology, vol. 25, no. 4, pp. 956-983, 1984. 
[31] F. Debon and P. le Fort, "A chemical-mineralogical classification of common plutonic rocks and associations," Transactions of the Royal Society of Edinburgh: Earth Sciences, vol. 73, no. 3, pp. 135149, 1983.

[32] W. J. Collins, S. D. Beams, A. J. R. White, and B. W. Chappell, "Nature and origin of A-type granites with particular reference to southeastern Australia," Contributions to Mineralogy and Petrology, vol. 80, no. 2, pp. 189-200, 1982.

[33] P. J. Pollard, "An intrusion-related origin for $\mathrm{Cu}-\mathrm{Au}$ mineralization in iron oxide-copper-gold (IOCG) provinces," Mineralium Deposita, vol. 41, no. 2, pp. 179-187, 2006.

[34] J. J. Wilkinson, "Fluid inclusions in hydrothermal ore deposits," Lithos, vol. 55, no. 1-4, pp. 229-272, 2001.

[35] M. Alavi, "Regional stratigraphy of the Zagros fold-thrust belt of Iran and its proforeland evolution," American Journal of Science, vol. 304, no. 1, pp. 1-20, 2004.

[36] J. Stocklin, "Structural history and tectonics of Iran: a review," American Association of Petroleum Geologists Bulletin, vol. 52, no. 7, pp. 1229-1258, 1968.

[37] L. E. Ricou, L'évolution géologique de la région de Neyriz (Zagros Iranien) et l'évolution structurale des Zagrides [Ph.D. thesis], Université Paris-Sud, Orsay, France, 1974.

[38] M. Berberian and G. C. P. King, "Towards a paleogeogaraphy and tectonic evolution of Iran," Canadian journal of earth sciences, vol. 18, no. 2, pp. 210-265, 1981.

[39] M. Alavi, "Tectonics of the zagros orogenic belt of iran: new data and interpretations," Tectonophysics, vol. 229, no. 3-4, pp. 211238, 1994.

[40] M. R. Sheikholeslami, A. Pique, P. Mobayen, M. Sabzehei, H. Bellon, and M. H. Emami, "Tectono-metamorphic evolution of the Neyriz metamorphic complex, Quri-Kor-e-Sefid area (Sanandaj-Sirjan Zone, SW Iran)," Journal of Asian Earth Sciences, vol. 31, pp. 504-521, 2008.

[41] M. R. Sheikholeslami, Evolution structurale et métamorphique de la marge sud de la microplaque de l'Iran central: les complexes métamorphiques de la région de Neyriz (Zone de SanandajSirjan) [Ph.D. thesis], Université de Brest, 2002.

[42] G. Alric and D. Virlogeux, Pétrographie et géochimie des roches métamorphiques et magmatiques de la région de Deh BidBavanat, Chaîne de Sanandaj-Sirjan, Iran [Ph.D. thesis], Université Scientifique et Médicale de Grenoble, Grenoble, France, 1977.

[43] J. Roshan Ravan and B. Amini, Geological map of the Kor-eSefid area, scale 1:100,000 geological survey of Iran, 1995.

[44] K. Sarkarinejad, "Quantitative finite strain and kinematic flow analyses along the Zagros transpression zone, Iran," Tectonophysics, vol. 442, no. 1-4, pp. 49-65, 2007.

[45] M. Mohajjel and C. L. Fergusson, "Dextral transpression in Late Cretaceous continental collision, Sanandaj-Sirjan Zone, western Iran," Journal of Structural Geology, vol. 22, no. 8, pp. 1125-1139, 2000.

[46] N. McQuarrie, "Crustal scale geometry of the Zagros foldthrust belt, Iran," Journal of Structural Geology, vol. 26, no. 3, pp. 519-535, 2004.

[47] K. Sarkarinejad, A. Faghih, and B. Grasemann, "Transpressional deformations within the Sanandaj-Sirjan metamorphic belt (Zagros Mountains, Iran)," Journal of Structural Geology, vol. 30, no. 7, pp. 818-826, 2008.

[48] A. Fazlnia, A. Moradian, K. Rezaei, M. Moazzen, and S. Alipour, "Synchronous activity of anorthositic and S-type granitic magmas in Chah-Dozdan batholith, Neyriz, Iran: evidence of
Zircon SHRIMP and Monazite CHIME dating," Journal of Sciences, Islamic Republic of Iran, vol. 18, no. 3, pp. 221-237, 2007.

[49] P. Ramdohr, The Ore Minerals and Their Intergrowths, Pregamon Press, Oxford, UK, 2nd edition, 1981.

[50] C. E. Vidal C., J. Injoque-Espinoza, G. B. Sidder, and S. B. Mukasa, "Amphibolitic Cu-Fe skarn deposits in the central coast of Peru," Economic Geology, vol. 85, no. 7, pp. 1447-1461, 1990.

[51] V. L. Rusinov, O. V. Rusinova, S. G. Kryazhev, Y. V. Shchegol'kov, E. I. Alysheva, and S. E. Borisovsky, "Wall-rock metasomatism of carbonaceous terrigenous rocks in the Lena gold district," Geology of Ore Deposits, vol. 50, no. 1, pp. 1-40, 2008.

[52] H. Forster and A. Jafarzadeh, "The Bafq mining district in central Iran; a highly mineralized Infracambrian volcanic field," Economic Geology, vol. 89, no. 8, pp. 1697-1721, 1994.

[53] L. Robb, Introduction to Ore-Forming Processes, Blackwell Publishing, Oxford, UK, 2005.

[54] B. W. Chappel and A. J. R. White, "Two contrasting granite types: expanded abstract," Pacific Geology, vol. 8, pp. 173-174, 1974.

[55] H. Wakita, P. Ray, and R. A. Schmitt, "Abundances of the 14 rare earth elements and 12 other trace elements in Apollo12 samples: five igneous and one breccia rocks and four soils," in Proceedings of the 2nd Lunar Sciences Conference, pp. 1319-1329, Oxford, UK, 1971.

[56] P. Henderson, Rare Earth Element Geochemistry, Elsevier, New York, NY, USA, 1989.

[57] D. E. Harlov, H.-J. Förster, and T. G. Nijland, "Fluid-induced nucleation of $(\mathrm{Y}+\mathrm{REE})$-phosphate minerals within apatite: nature and experiment. Part I. Chlorapatite," The American Mineralogist, vol. 87, no. 2-3, pp. 245-261, 2002.

[58] J. N. Rubin, C. D. Henry, and J. G. Price, "The mobility of zirconium and other "immobile" elements during hydrothermal alteration,” Chemical Geology, vol. 110, no. 1-3, pp. 29-47, 1993.

[59] T. J. Shepherd, A. H. Rankin, and D. H. M. Alderton, A Practical Guide to Fluid Inclusion Studies, Blackie Press, 1985.

[60] J. W. Hedenquist and R. W. Henley, "The importance of $\mathrm{CO}_{2}$ on freezing point measurements of fluid: evidence from active geothermal systems and implications for epithermal ore deposition," Economic Geology, vol. 80, no. 5, pp. 1379-1406, 1985.

[61] R. Powell, T. M. Will, and G. N. Phillips, "Metamorphism in Archaean greenstone belts: calculated fluid compositions and implications for gold mineralization," Journal of Metamorphic Geology, vol. 9, no. 2, pp. 141-150, 1991.

[62] A. M. Evans, An Introduction to Ore Geology, Blackwell Scientific Publications, Oxford, UK, 1987.

[63] H. R. Naslund, F. Henríquez, J. O. Nyström, W. Vivallo, and F. M. Dobbs, "Magmatic iron ores and associated mineralisation: examples from the Chilean High Andes and Costal Cordillera," in Hydrothermal Iron Oxide Copper-Gold and Related Deposits: A Global Perspective 2, T. M. Porter, Ed., pp. 207-226, PGC Publishing, Adelaide, Australia, 2002.

[64] O. Martinsson, Geology and Metallogeny of the Northern Norrbotten Fe-Cu-Au Province, Guidebook Series 33, Society of Economic Geologists, 2004.

[65] M. W. Hitzman and R. K. Valenta, "Uranium in iron oxidecopper-gold (IOCG) systems," Economic Geology, vol. 100, no. 8, pp. 1657-1661, 2005.

[66] A. R. Philpotts, "Compositions of immiscible liquids in volcanic rocks," Contributions to Mineralogy and Petrology, vol. 80, no. 3, pp. 201-218, 1982. 
[67] J. R. Weidner, "Iron-oxide magmas in the system Fe-C-O.," Canadian Mineralogist, vol. 20, no. 4, pp. 555-566, 1982.

[68] B. G. Lottermoser, "Rare earth elements and hydrothermal ore formation processes," Ore Geology Reviews, vol. 7, no. 1, pp. 2541, 1992.

[69] D. H. M. Alderton, J. A. Pearce, and P. J. Potts, "Rare earth element mobility during granite alteration: evidence from southwest England," Earth and Planetary Science Letters, vol. 49, no. 1, pp. 149-165, 1980.

[70] M. J. Apted and J. G. Liou, "Phase relations among greenschist, epidote-amphibolite, and amphibolite in a basaltic system," The American Journal of Science, vol. 283, pp. 328-354, 1983.

[71] R. L. Nielsen, J. S. Beard, and M. L. Hilyard, "emperature and compositional controls on the mineral-melt partitioning of the high field strength and rare earth elements for amphibole and magnetite," in Proceedings of the 7th Annual V. M. Goldschmidt Conference, Tucson, Ariz, USA, 1997.

[72] H. H. Schock, "Distribution of rare-earth and other trace elements in magnetites," Chemical Geology, vol. 26, no. 1-2, pp. 119-133, 1979.

[73] R. Frietsch and J.-A. Perdahl, "Rare earth elements in apatite and magnetite in Kiruna-type iron ores and some other iron ore types," Ore Geology Reviews, vol. 9, no. 6, pp. 489-510, 1995.

[74] J. de Sitter, A. Govaert, E. de Grave, D. Chambaere, and G. Robbrecht, "A mössbauer study of $\mathrm{Ca}^{2+}$-containing magnetites," Physica Status Solidi A, vol. 43, no. 2, pp. 619-624, 1977.

[75] D. A. Sverjensky, "Europium redox equilibria in aqueous solution," Earth and Planetary Science Letters, vol. 67, no. 1, pp. 7078, 1984.

[76] C. Zhu and D. A. Sverjensky, "Partitioning of F-Cl-OH between minerals and hydrothermal fluids," Geochimica et Cosmochimica Acta, vol. 55, no. 7, pp. 1837-1858, 1991.

[77] I. M. Chou and H. P. Eugster, "Fugacity control and dissociation constants of $\mathrm{HBr}$ and $\mathrm{HI}$," Contributions to Mineralogy and Petrology, vol. 56, no. 1, pp. 77-100, 1976.

[78] T. M. Seward and H. L. Barnes, "Metal transport by hydrothermal ore fluids," in Geochemistry of Hydrothermal Ore Deposits, H. L. Barnes, Ed., pp. 435-486, Wiley, New York, NY, USA, 3rd edition, 1997.

[79] H. L. Barnes, Geochemistry of Hydrothermal Ore Deposits, John Wiley \& Sons, New York, NY, USA, 1997.

[80] S. A. Wood and I. M. Samson, "Solubility of ore minerals and complexation of ore metals in hydrothermal solutions," in Techniques in Hydrothermal Ore Deposit Geology, Reviews in Economic Geology, pp. 33-80, Society of Economic Geologists, 1998.

[81] L. Kalender, A. Sagiroglu, and S. Kisman, "Fluid inclusion studies in the different origin quartzes associated with $\mathrm{Cu}$ $\mathrm{Pb}-\mathrm{Zn}$ mineralizations at Kizildag and Köprücük-Harput, east Anatolian district, Turkey," Ozean Journal of Applied Sciences, vol. 2, pp. 127-138, 2009. 

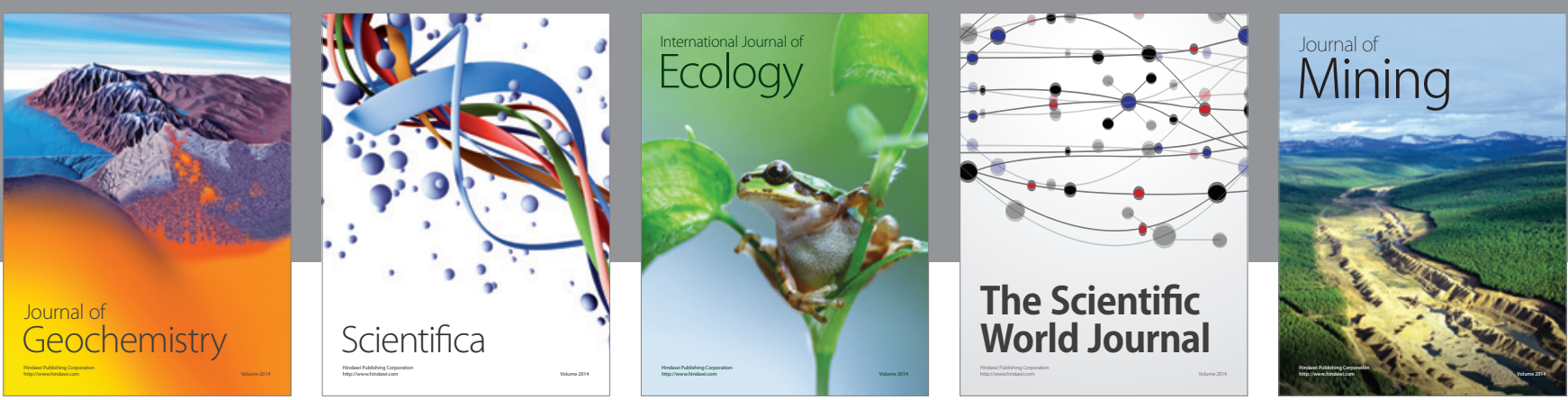

The Scientific World Journal
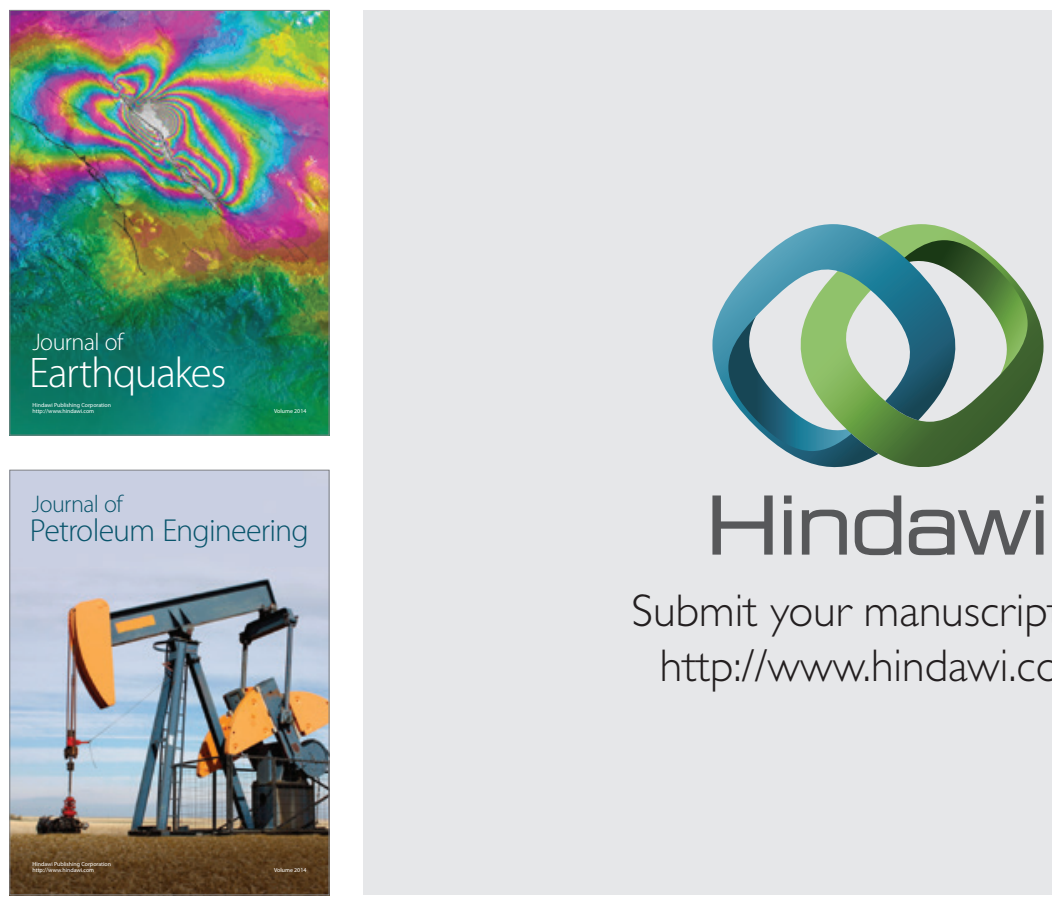

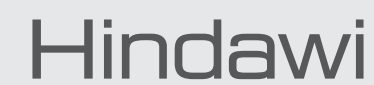

Submit your manuscripts at

http://www.hindawi.com
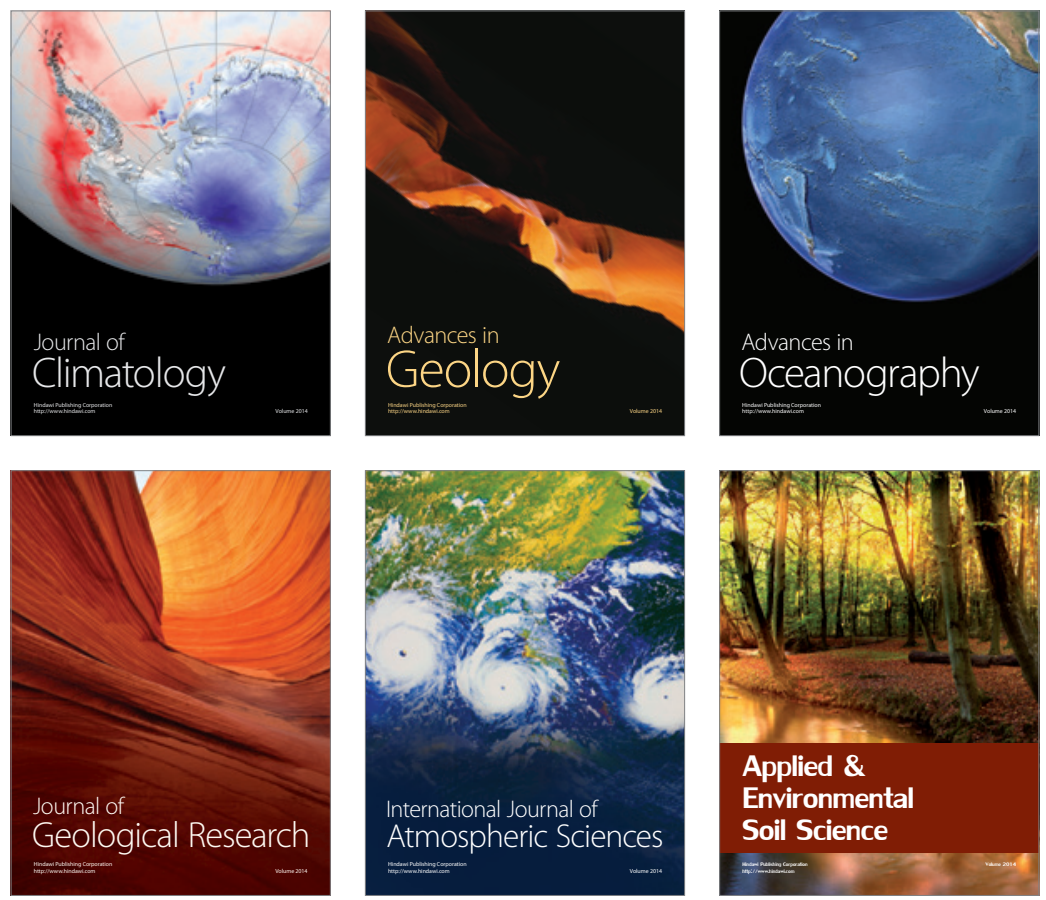
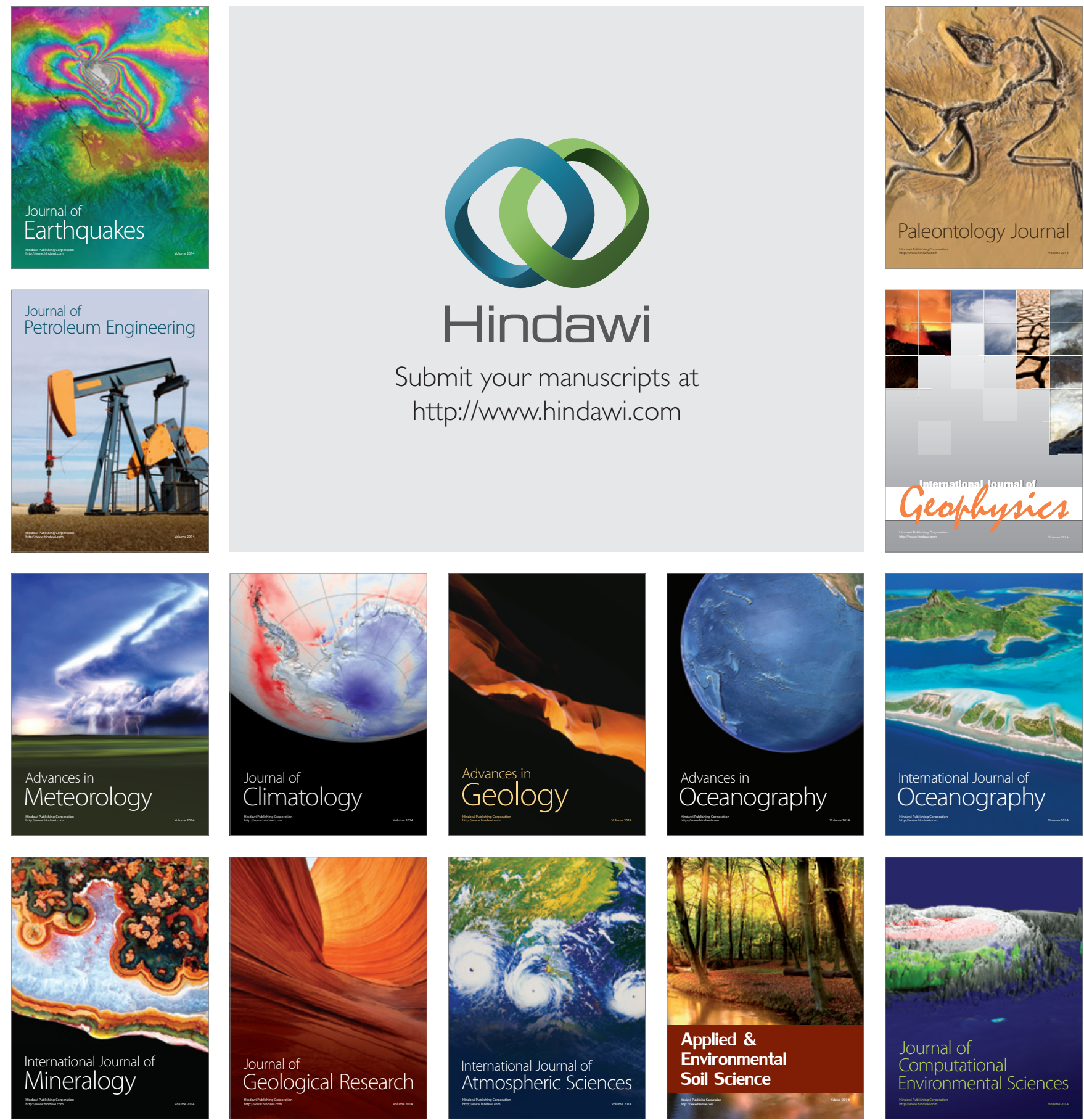